\title{
Kidney organoids: accurate models or fortunate accidents
}

\author{
Melissa H. Little ${ }^{1,2,3}$ and Alexander N. Combes ${ }^{1,2}$ \\ ${ }^{1}$ Murdoch Children's Research Institute, Parkville, Victoria 3052, Australia; ${ }^{2}$ Department of Anatomy and Neuroscience, The \\ University of Melbourne, Victoria 3052, Australia; ${ }^{3}$ Department of Paediatrics, The University of Melbourne, Victoria 3052 , \\ Australia
}

There are now many reports of human kidney organoids generated via the directed differentiation of human pluripotent stem cells (PSCs) based on an existing understanding of mammalian kidney organogenesis. Such kidney organoids potentially represent tractable tools for the study of normal human development and disease with improvements in scale, structure, and functional maturation potentially providing future options for renal regeneration. The utility of such organotypic models, however, will ultimately be determined by their developmental accuracy. While initially inferred from mouse models, recent transcriptional analyses of human fetal kidney have provided greater insight into nephrogenesis. In this review, we discuss how well human kidney organoids model the human fetal kidney and how the remaining differences challenge their utility.

Directed differentiation of human pluripotent stem cells to specific cellular endpoints has opened up the possibility of tissue regeneration for an increasing variety of human tissue types. The organotypic self-organization of cells within differentiating human pluripotent stem cell (hPSC) cultures to form what are now referred to as "organoids" (Lancaster and Knoblich 2014) has provided researchers with complex multicellular models of developing human tissues including optic cup, intestine, cerebral cortex, stomach, pituitary, colon, and lung (Eiraku et al. 2011; Spence et al. 2011; Lancaster et al. 2013; McCracken et al. 2014; Ozone et al. 2016; Múnera et al. 2017; Miller et al. 2018) to name a few. In each example, the approach taken has been to try to recapitulate the signaling events required to move the pluripotent stem cell population through an appropriate primary germ layer and on to a specific tissue endpoint in a stepwise fashion. While the cellular complexity, transcriptional congruence, and tissue morphology achieved has been remarkable, with clear parallels to developmental organogenesis, all such

[Keywords: kidney development; metanephros; pluripotent stem cell; kidney organoid; nephron progenitor; podocyte; collecting duct; single-cell transcriptional profiling]

Corresponding author: melissa.little@mcri.edu.au

Article is online at http://www.genesdev.org/cgi/doi/10.1101/gad.329573. 119. models represent a developing tissue model, usually no more mature than human trimester 2. Nevertheless, this has represented an unparalleled approach to modeling human tissue in vitro. The development of protocols for the recreation of the kidney is of great interest to the field of nephrology who have previously either relied on the mouse as a molecular and cellular model of mammalian kidney development or used primary or immortalized cell types to understand development and disease.

The kidney is a very complex tissue, comprising $>25$ distinct cell types in the postnatal organ. The functions of the kidney include fluid homeostasis, removal of nitrogenous waste products, and the regulation of blood pressure, bone density, and red cell count. Kidney disease can result from inherited mutations but can also arise after chronic injury, such as inflammatory disease and diabetes. A major target of toxic injury, the kidney is also significantly susceptible to drug-induced toxicity. As a result of all these conditions, chronic kidney disease is growing at $6 \%$ per annum worldwide, whereas end-stage kidney disease remains treatable only via transplantation or dialysis. The advent of stem cell-derived models of the human kidney have understandably been of significant interest to the nephrology community as potential models for the screening of drugs, improved understanding of disease aetiology, and sources of replacement renal tissue. However, at present, kidney organoids are a model and are some way from representing the human kidney itself. As has been the case for other hPSC-derived organoids, they are recognizable as a model of the developing human kidney and not the functional postnatal kidney. Indeed, their capacity to model even the developing kidney is still being fully examined. In this review, we pose the question of whether kidney organoids do indeed represent accurate avatars with which to model human kidney disease or to understand human kidney development and, if not, what advances are needed to improve their utility.

(C) 2019 Little and Combes This article is distributed exclusively by Cold Spring Harbor Laboratory Press for the first six months after the full-issue publication date (see http://genesdev.cshlp.org/site/misc/terms.xhtml). After six months, it is available under a Creative Commons License (Attribution-NonCommercial 4.0 International), as described at http://creativecommons.org/licenses/by-nc/4.0/. 


\section{The development of the mammalian kidney}

To understand how kidney organoids are recognizable as a developing kidney requires a deep understanding of how the mammalian kidney forms. Adult kidneys arise as a result of interactions between two key cell populationsthe nephric duct and the metanephric mesenchyme. Both populations are specified in the intermediate mesoderm, which is derived from the primitive streak and regionalized by signals restricted in time and space (Little et al. 2016). The nephric duct originates in the anterior intermediate mesoderm, while the metanephric mesenchyme derives from the posterior intermediate mesoderm (Taguchi et al. 2014; Xu et al. 2014). The nephric duct and the precursor for the metanephric mesenchyme (the nephrogenic cord) sit adjacent to each other and interact to form three paired kidney structures (the pronephros, mesonephros, and metanephros) across developmental time (Fig. 1A; Saxen and Sariola 1987). While the metanephros is the only structure to persist into adulthood in amniotes, nephron-like structures form within the pronephros and mesonephros via a mesenchyme to epithelial transition in response to canonical WNT signaling from the nephric duct (Carroll et al. 2005) and display similar patterning to early-stage nephrons in the metanephric kidney (Fig. 1AC; Mugford et al. 2008b; Georgas et al. 2011). Formation of the metanephric kidney occurs in the posterior region of the embryo near the hindlimb buds as the nephrogenic cord condenses into a comet-shaped mass referred to as the metanephric mesenchyme (Fig. 1D; Wainwright et al. 2015). This is distinguished from the rest of the nephrogenic cord by expression of Hox 11 genes, which are involved in specification of the metanephric kidney and the posterior of the embryo (Wellik et al. 2002; Mugford et al. 2008a). GDNF signaling from the metanephric mesenchyme to RET receptor tyrosine kinase and coreceptors in the nephric duct induces outgrowth of the ureteric bud (Fig. 1E; Costantini and Kopan 2010). The site of ureteric bud outgrowth is tightly regulated; however, anterior nephric duct is also capable of budding given appropriate signals (Costantini and Kopan 2010; Taguchi and Nishinakamura 2017).

The ureteric bud, stromal, and nephron progenitor cells in the metanephric mesenchyme establish the main lineages of the developing kidney. Six $2^{+}$Cited $1^{+}$nephron progenitor cells give rise to all segments of the epithelial nephrons (Boyle et al. 2008; Kobayashi et al. 2008), the entire ureteric epithelium derives from Ret+ ureteric tip cells (Chi et al. 2009), and Foxd $1^{+}$stromal progenitors give rise to the majority of renal stromal cell types (Kobayashi et al. 2014), complemented by Tbx18-derived stromal cells (Bohnenpoll et al. 2013), which arise as the ureteric bud grows into the metanephric mesenchyme. Other major cell types in the developing kidney include macrophages (Rae et al. 2007; Munro et al. 2019), vasculature (Munro et al. 2017; Daniel et al. 2018), and nerves (Sariola et al. 1988). The extent to which these latter cell types influence organogenesis is still emerging.

Kidney growth is driven by reciprocal interactions between stromal, ureteric tip, and nephron progenitor popu- lations in the periphery of the kidney. These populations, together with the surrounding vasculature, form the nephrogenic niche. Factors including GDNF, FGF, and BMP ligands produced by nephron progenitors promote proliferation and branching morphogenesis in the underlying tip (Costantini and Kopan 2010). In response, BMP, FGF, and low levels of canonical Wnt signals in the top of the ureteric tip support nephron progenitor identity and proliferation, maintaining a pool of progenitors to continue to support branching morphogenesis (Fig. 1B,E; Karner et al. 2011; Barak et al. 2012; Brown et al. 2015; O'Brien et al. 2018). It is proposed that higher levels of WNT9B expression in the ureteric tip-stalk junction triggers adjacent nephron progenitors to undergo a mesenchyme-to-epithelial transition to form an early nephron (Fig. 1B,E; Carroll et al. 2005). Nephron commitment is dependent on canonical Wnt activity and can be induced by pharmacological stabilization of the Wnt transcriptional effector $\beta$-catenin (Kuure et al. 2007). Notch signaling is also required and sufficient for nephron progenitor differentiation into the early epithelial nephron, presumably downstream from canonical Wnt (Fujimura et al. 2010; Chung et al. 2016). Fox $d 1^{+}$cells within the nephrogenic zone stroma contribute to regulation of the niche, at least in part through atypical cadherin FAT4, which is proposed to promote differentiation in nearby nephron progenitors via cell-cell interactions (Das et al. 2013; Bagherie-Lachidan et al. 2015). Signaling input from the vasculature to the nephrogenic niche is likely but as yet undefined. Indeed, signaling from the forming nephrons back to the adjacent nephron progenitors, ureteric epithelium, and stroma is also likely but uncharacterized.

\section{Nephron commitment, patterning, and segmentation}

The self-sustaining nephrogenic niche at the periphery of the developing organ drives kidney growth through consecutive rounds of branching and nephron induction. As a result, the kidney rapidly develops complex threedimensional architecture with molecular patterning evident in each major lineage. Mature nephrons are comprised of specialized segments that regulate fluid balance, solute uptake, and excretion of metabolic waste. These include a connecting segment that joins the nephron to the ureteric tip, followed by the distal tubule, Loop of Henle that drops into the medullary stroma, proximal tubule that rises back up to the cortex, and podocytes that encase a capillary bed to facilitate blood filtration (Fig. 1E). Patterning of the early nephron first emerges as induced progenitors aggregate and transition into an epithelial cyst referred to as the renal vesicle. The distal portion of the renal vesicle, closest to the ureteric tip, features elevated levels of Wnt4, Lhx1, Bmp2, Jag1, and Dll1, whereas the proximal portion is marked by Wt1 (Georgas et al. 2009). This early patterning is propagated into subsequent Comma- and S-shaped body stages named after the morphology of the forming nephron (Fig. 1E). By the S-shaped body stage distinct distal, medial, and proximal domains are evident, which are assumed to represent 
A

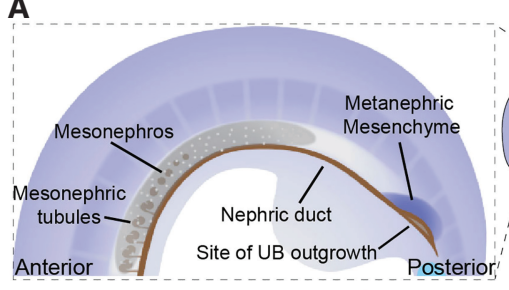

C

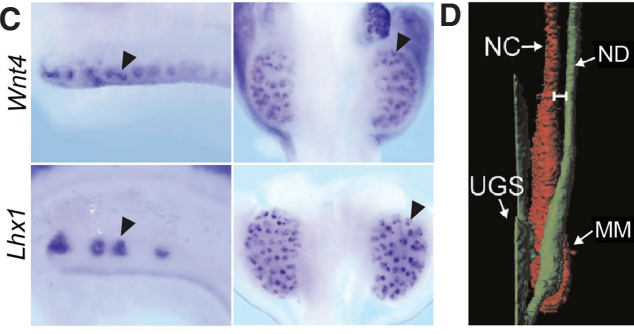

$\mathbf{F}$
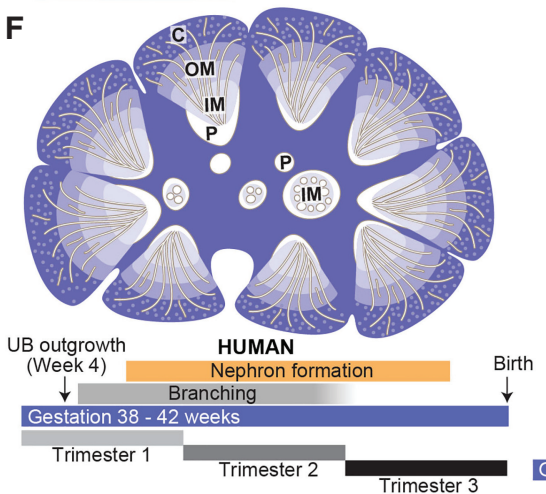

H

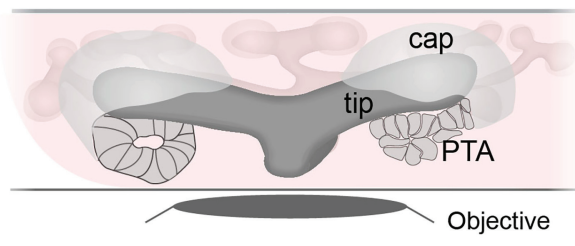

B

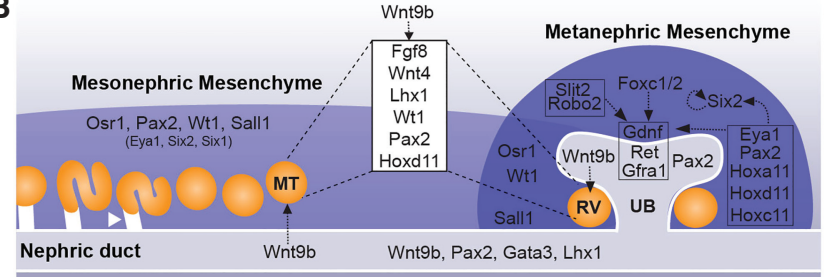

E
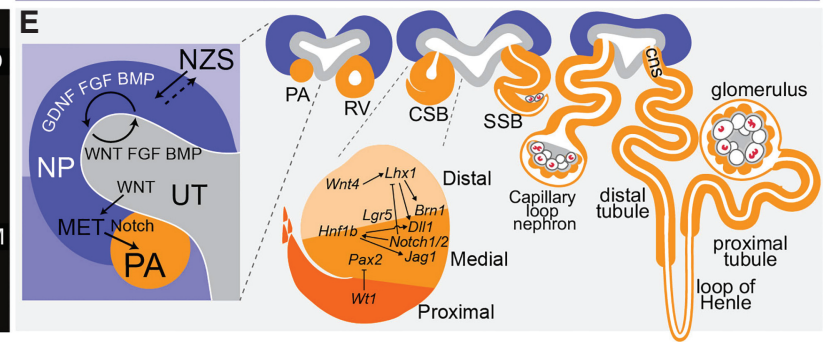

G
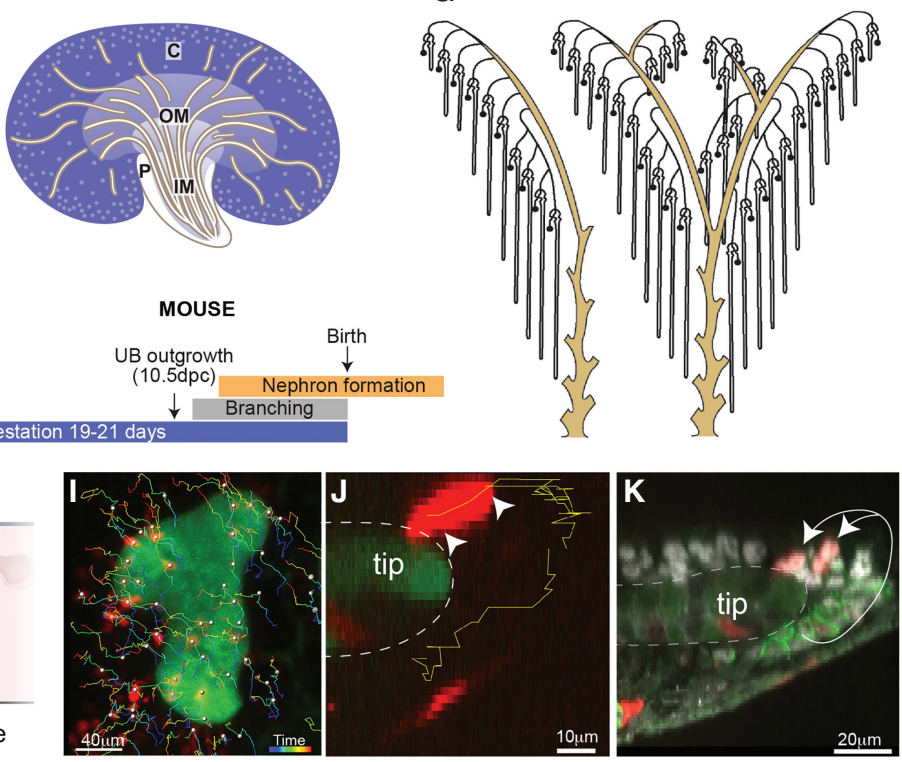

Figure 1. An overview of mammalian kidney development. (A) Positioning of the metanephric mesenchyme and mesonephric tubules within the developing mouse embryo at $\sim 10 \mathrm{~d}$ of embryonic development. The mesonephros and metanephric mesenchyme lie adjacent to the nephric duct, from which the ureteric bud (UB) arises. Adapted from http://www.gudmap.org/tutorials/urogenital-dev/devmus .html. (B) Comparison of gene expression and nephron induction in the mesonephric and metanephric mesenchyme. Solid arrows indicate known regulatory relationships. (MT) Mesonephric tubules; (RV) renal vesicle; (UB) ureteric bud. Adapted from Georgas et al. (2011). (C) Expression of key nephron markers in E10.5 mesonephric tubules (left panel) and E13.5 metanephric nephrons (right panel). Adapted from Georgas et al. (2011). (D) 3D rendering of the nephrogenic cord (NC), adjacent to the nephric duct (ND), and urogenital sinus (UGS). Reprinted from Wainwright et al. (2015) with permission from Elsevier. (E) Overview of reciprocal signaling and inductive relationships in the nephrogenic niche, nephron patterning, and maturation. (NZS) Nephrogenic zone stroma; (NP) nephron progenitor; (UT) ureteric tip; (PA) pretubular aggregate; (MET) mesenchyme to epithelial transition; (RV) renal vesicle; (CSB and SSB) comma- and S-shaped body; (cns) connecting segment. $(F)$ Comparison of timeline and gross morphology of kidney development in humans and mice. Adapted from Little (2015). (G) Illustration of nephron arcading in the human kidney (https://abdominalkey.com/development-of-the-kidney). (H) Illustration of live imaging setup for developing mouse kidney explant cultures from Lawlor et al. (2019). (I) Tracking nephron progenitor cell movement (red dots and lines) over time. Ureteric tip is shown in green. (I-K) Cells labeled (red) with an inducible Cre driven by the Wnt4 promoter in the early committing nephron can integrate back into the progenitor population by cell migration. Green in $I$ and $J$ is GFP expression in the tip, green in $K$ is NCAM staining, and white staining in $K$ shows expression of nephron progenitor marker SIX2. $I$ is from Combes et al. (2019a); $J$ and $K$ are from Lawlor et al. (2019).

segment-restricted precursor populations based on the expression of marker genes that are later specific to corresponding mature nephron segments. Indeed, lineage tracing of $\mathrm{Lgr}^{+}$cells in the early distal nephron labels mature distal tubule and part of the adjoining Loop of Henle (Barker et al. 2012). While the initial drivers of nephron patterning are unclear, this may include regionalized signals derived from the adjacent ureteric epithelium 
and other surrounding cell types. Several genes with restricted expression patterns in the early nephron play important roles in patterning. Renal vesicles lacking Wnt4 fail to progress to Comma or S-shaped bodies (Stark et al. 1994). Nephrons lacking $L$ hx1 fail to form a proximal-distal axis and lack expression of LHX1 target genes Brn1 and Dll1 (Kobayashi et al. 2005) and Brn1 is subsequently required for correct formation of distal and medial nephron segments (Nakai et al. 2003). Hnf1b is restricted to the medial segment of the S-shaped body. Removal of this gene from forming nephrons results in a down-regulation of Notch regulators Dll1 and Jag1 followed by dramatic loss of proximal and medial nephron segments, with abnormal glomeruli connecting to the ureteric epithelium through a truncated distal tubule (Heliot et al. 2013). Likewise, Wt1 regulates podocyte transcriptional programs (Dong et al. 2015; Kann et al. 2015; Lefebvre et al. 2015) in the proximal nephron, and may repress distal and medial nephron fates by repressing Pax2 (Ryan et al. 1995). Indeed, the proximal nephron does not express Cdh1, suggesting a distinct cell-cell adhesion property to the distal nephron (Georgas et al. 2009). Both Wnt and Notch signaling have been implicated in establishing nephron patterning. A gradient of Wnt activity is evident in the renal vesicle and S-shaped body with highest levels in the distal nephron, moderate levels in the medial segment, and low activity in the proximal nephron (Lindstrom et al. 2015). Promoting canonical Wnt signaling in culture favors formation of distal nephron segments, whereas Wnt inhibition favors proximal fates (Lindstrom et al. 2015). Genetic or pharmacological disruption of Notch signaling also has a profound impact on nephron formation (McCright et al. 2001; Cheng et al. 2003, 2007; Surendran et al. 2010; Chung et al. 2017). While initial studies proposed a major role for Notch signaling in regulating proximal nephron fate, recent work demonstrates that deletion of Notch1 and Notch2 from nephron progenitors or the early committing nephron results in a failure to progress past renal vesicle stage and a lack of all subsequent nephron segments (Chung et al. 2016, 2017). Conversely, ectopic activation of Notch signaling in nephron progenitors or early developing nephrons promoted nephron formation but did not bias cell fate towards a proximal identity (Fujimura et al. 2010; Chung et al. 2017). However, early loss of Notch receptors from nephron progenitors did disrupt proximal-distal patterning, with the expression domain of LHX1 expanded into the proximal renal vesicle, and lower levels of HNF1B in the aberrant early nephrons that did form (Chung et al. 2017). Likewise, the lack of proximal nephrons in Hnf1b conditional knockout models may be mediated by dysregulation of notch ligands including Dll1 and Jag1 in the medial and proximal S-shaped body (Heliot et al. 2013). Study of the mechanisms regulating specification and patterning of nephron segments has been hampered by key regulatory components playing multiple roles in different aspects of nephron formation and broader kidney development. However, advances in imaging (Lindstrom et al. 2018d) and single-cell sequencing (covered below) are delivering unprecedented insight into the cell types and regulatory programs that govern nephron patterning.

Similar to the developing nephron, the ureteric bud develops into a branched network with distinct zones of gene expression defining tip, stalk, and medullary domains of this epithelium (Thiagarajan et al. 2011; Rutledge et al. 2017). Ultimately, the ureteric epithelium serves to collect urinary filtrate from the nephrons and channel this through the renal pelvis and out a single ureter to the bladder. The renal stroma is also divided into distinct anatomical regions that are reflected in unique gene expression profiles including the nephrogenic zone, cortical, and medullary zones, as well as specialized stroma surrounding the ureter (Thiagarajan et al. 2011; Magella et al. 2018; Combes et al. 2019a,b). The importance of crosstalk between cell compartments within these regions remains to be determined, but interactions between cell types in the nephrogenic zone as described above and ureter mesenchyme (Yu et al. 2002) suggest that patterning and regionalized interactions are essential to development of a functional kidney.

\section{Anatomical and molecular comparisons between mouse and human kidney development}

Human kidney development has obvious differences from that of the mouse in terms of scale, timing, and gross morphology. Human kidneys develop over $30+$ wk from ureteric bud outgrowth compared with just over a week in mice (Fig. 1F; Osathanondh and Potter 1963; Little 2015; Lindstrom et al. 2018c). Human kidneys also have a distinct lobed structure not apparent in the mouse kidney (Treuting and Kowalewska 2011) and nephrons continue to form after branching has ceased by "arcading" where up to seven nephrons connect to each other in series and back into a single tip (Fig. 1G; Osathanondh and Potter 1963; Oliver 1968). The morphology of these arcading nephrons suggests the intriguing possibility of a partially committed nephron progenitor cell population that persists independent of the nephrogenic niche for a sustained period of embryogenesis. The capacity for nephrons to connect to other nephrons, rather than the ureteric tip, may also be unique to human kidney development, although there is one report describing a process of arcading within nephrons of the mouse kidney (Zhai et al. 2006). Despite these differences, genes that cause renal phenotypes when disrupted in mice are linked to similar outcomes in humans, suggesting some conservation of molecular mechanisms (Vivante et al. 2014; Vivante and Hildebrandt 2016).

Although images of fixed tissue show cells in an ordered state, mouse kidney development in vivo is a highly dynamic process. Time-lapse imaging has revealed that nephron progenitor cells move within and between adjacent niches, attaching and detaching from the ureteric tip, with these behaviors influencing their capacity to commit (Fig. 1H-K; Combes et al. 2016; O'Brien et al. 2018; Lawlor et al. 2019). These motile progenitors swarm around the tips of the ureteric epithelium, which are 
branching at a rapid rate (Cebrián et al. 2004; Watanabe and Costantini 2004). Each branching event divides the cells within the ureteric tip and the surrounding nephron progenitors in two, driving a decrease in the size of the nephrogenic niche (Combes et al. 2014; Short et al. 2014). While such live imaging has not been possible in humans, similar changes in niche size and accompanying changes in morphology are observed during human kidney development (Lindstrom et al. 2018c). Rapid rates of branching and cell proliferation gradually slow across development until birth in mice (Short et al. 2014) or 36 wk of gestation in humans when nephron progenitors undergo a final burst of commitment (Hartman et al. 2007; Rumballe et al. 2011). In mouse, this commitment event results in up to five nephrons connecting to a single tip (Rumballe et al. 2011). After this point, nephron number is set and any insult or injury that reduces nephron number or function must be compensated for by hyperfiltration from remaining nephrons. In this respect, both mouse and human are the same.

Recent anatomical and molecular comparisons between human and mouse kidney development have clarified points of similarity and divergence between the species (Lindstrom et al. 2018b,c,d). Early human kidney development bears a striking resemblance to mouse with outgrowth of the ureteric bud and early branching and nephron induction events conserved at a morphological level, albeit on a longer time scale (Lindstrom et al. $2018 \mathrm{c}$ ). This longer time scale of nephron formation in humans led to new insight into nephron patterning. Nephron progenitor cells were observed to "stream" into the early committing nephron in human. Subsequent mouse studies showed the timing of progenitor recruitment predicts cell position and fate in the S-shaped body stage where nephron patterning is first evident (Lindstrom et al. 2018a). Cell type-specific antibodies established in mouse were used to visualize equivalent cell populations in the developing human kidney though several marker genes established in mouse were not expressed in the human kidney or were expressed in different regions (Lindstrom et al. 2018c). Detailed comparison of nephron formation and patterning between human and mouse revealed strong conservation between species and yielded additional insight into early nephron patterning (Lindstrom et al. 2018d). Comparison of nephron and stromal progenitors in the renal cortex again revealed a conservation of most established markers from each population from mouse with some distinct differences. The transcriptional regulator SIX1 continues to be expressed in human nephron progenitors and appears to be functionally redundant with family member SIX2 (O'Brien et al. 2016). In contrast, mouse Six1 is down-regulated prior to nephrogenesis and Six2 plays an essential and nonredundant role in nephron progenitor maintenance (Self et al. 2006). A prominent point of difference to mouse is the transcriptional profile of stromal and nephron progenitors, which overlaps to a greater extent in human, including key stromal transcription factors such as FOXD1, which are exclusive to stromal progenitors in mouse (Lindstrom et al. 2018b). The morphological characteriza- tion and transcriptional profiling of whole human fetal kidneys from 9 to 21 wk of development (Lindstrom et al. 2018c) and isolated human stromal and nephron progenitors (Lindstrom et al. 2018b) provides a valuable reference for human kidney development and has served to provide context for recent single-cell profiles of the developing human kidney.

The advent of single-cell RNA-sequencing (scRNA-seq) has coincided with a surge in research involving human fetal kidney tissue. This convergence has accelerated the characterization of cell types, marker genes, and inferred lineage relationships in human kidney development. Covering an age range of 7-25 wk of embryonic development, several studies resolved clusters representing cell types from the stromal, nephron, and ureteric epithelium lineages as well as endothelial, blood, and immune cells (Table 1; Lindstrom et al. 2018a,b; Menon et al. 2018; Wang et al. 2018; Young et al. 2018; Hochane et al. 2019). One study also detected a low number of neural precursor cells (Young et al. 2018). Each cell type within the human fetal kidney is identifiable by expression of marker genes established in mice but closer inspection reveals species-specific differences. As such, these data have served as a primary reference for comparison to cell types within human iPSC-derived organoids (Wu et al. 2018; Combes et al. 2019b). Pseudotime analysis of single cells is a computational method to organize the transcriptional profiles of each cell along a developmental trajectory, enabling inference of cell state transitions and lineage relationships (Trapnell et al. 2014). Such analyses applied to single cells from the human fetal kidney largely replicate the expected developmental trajectory from nephron progenitor to more mature nephron cell states though the branch points identifying the divergence between progenitor and podocyte, proximal, and distal nephron fates vary between studies (Lindstrom et al. 2018a; Menon et al. 2018; Wang et al. 2018; Hochane et al. 2019). For example, Lindstrom et al. (2018a) report human podocytes developing along a trajectory distinct from the precursors of the proximal and distal nephron, whereas results from Hochane et al. (2019) identify podocytes diverging after a common precursor state that also gives rise to proximal and distal tubular fates. Heterogeneity within the nephron progenitor population is evident in most studies, though the biological significance of differences between the subpopulations is not always clear. Cells of the ureteric epithelium appear to be underrepresented in all data sets, potentially as a result of a dissociation bias against cells with strong cell-cell adhesion. As such, insight into this lineage has been limited but there is support for maintenance of progenitors in the ureteric tip and a distinct stalk/trunk identity (Rutledge et al. 2017; Menon et al. 2018). Within the stromal lineage, several distinct clusters were identified in each study, but our understanding of the identity and location of these populations is still emerging. While these profiles represent a major step forward in understanding the cellular composition of the human fetal kidney, several definitive marker genes and signaling pathway components like Wnt, FGF, and TGFB ligands, and ureteric epithelium markers WNT11 
Table 1. Available transcriptional profiling of human fetal kidney and human kidney organoids

\begin{tabular}{|c|c|c|c|c|}
\hline $\begin{array}{l}\text { Human fetal } \\
\text { kidney }\end{array}$ & Age/stage & Transcriptional profiling & Analysis and conclusion & Reference \\
\hline $\begin{array}{l}\text { ITGA } 8^{+} \text {cells from } \\
\text { human fetal } \\
\text { kidney }\end{array}$ & Week 17 fetal kidney & Bulk RNA-seq & $\begin{array}{l}\text { Comparative ChIP-seq and RNA- } \\
\text { seq between mouse and } \\
\text { human nephron progenitors } \\
\text { show that SIX1 is functionally } \\
\text { redundant with SIX2 in the } \\
\text { human fetal kidney }\end{array}$ & $\begin{array}{l}\text { O'Brien et al. } \\
2016\end{array}$ \\
\hline $\begin{array}{l}\text { Human fetal } \\
\text { kidney }\end{array}$ & Week 9-21 fetal kidney & Bulk RNA-seq & $\begin{array}{l}\text { Progenitor genes enriched at } \\
\text { early time points, genes } \\
\text { associated with maturing } \\
\text { nephrons, and ureteric } \\
\text { epithelium enriched at later } \\
\text { time points }\end{array}$ & $\begin{array}{l}\text { Lindstrom } \\
\text { et al. } 2018 \mathrm{c}\end{array}$ \\
\hline $\begin{array}{l}\text { Nephron and } \\
\text { stromal } \\
\text { progenitor cells } \\
\text { from human } \\
\text { fetal kidney } \\
\text { cortex }\end{array}$ & Week 16 fetal kidney & $\begin{array}{l}\text { Bulk RNA-seq of nuclear- } \\
\text { isolated SIX2 } 2^{+} \text {nephron } \\
\text { progenitor cells and } \\
\text { MEIS1 }^{+} \text {Six } 2^{-} \text {stromal } \\
\text { progenitor cells }\end{array}$ & $\begin{array}{l}\text { Comparative analysis of mouse } \\
\text { and human nephron and } \\
\text { stromal progenitor cells } \\
\text { reveals conserved and } \\
\text { divergent features within the } \\
\text { nephrogenic niche between } \\
\text { these species }\end{array}$ & $\begin{array}{l}\text { Lindstrom } \\
\text { et al. } 2018 b\end{array}$ \\
\hline $\begin{array}{l}\text { Human fetal } \\
\text { kidney }\end{array}$ & $\begin{array}{l}\text { Pooled Trimester } 1 / 2 \\
\text { (87-132 d of gestation) }\end{array}$ & $\begin{array}{l}\text { Dropseq, Single-cell } \\
\text { RNA-seq; }>6000 \text { cells }\end{array}$ & $\begin{array}{l}\text { Comprehensive dynamic map of } \\
\text { gene expression in human } \\
\text { fetal kidneys }\end{array}$ & $\begin{array}{l}\text { Menon et al. } \\
2018\end{array}$ \\
\hline $\begin{array}{l}\text { Renal tumors, } \\
\text { adult kidney, } \\
\text { pediatric kidney, } \\
\text { fetal kidney }\end{array}$ & Varied & $\begin{array}{l}\text { Dropseq, single-cell } \\
\text { RNA-seq; } 72,000 \text { cells }\end{array}$ & $\begin{array}{l}\text { Evidence that Wilms' tumours } \\
\text { represent an aberrant fetal } \\
\text { stage of development; } \\
\text { dentification of cellular } \\
\text { components within specific } \\
\text { renal carcinomas }\end{array}$ & $\begin{array}{l}\text { Young et al. } \\
2018\end{array}$ \\
\hline $\begin{array}{l}\text { Human fetal } \\
\text { kidney, cortical } \\
\text { region }\end{array}$ & Week 16 fetal kidney & $\begin{array}{l}\text { Chromium 10x, single cell } \\
\text { RNA-seq, } 2750 \text { cells }\end{array}$ & $\begin{array}{l}\text { Benchmark of cell types within } \\
\text { human fetal kidney } \\
\text { nephrogenic zone }\end{array}$ & $\begin{array}{l}\text { Lindstrom } \\
\text { et al. } 2018 \mathrm{~d}\end{array}$ \\
\hline $\begin{array}{l}\text { Human fetal } \\
\text { kidney, cortical } \\
\text { region }\end{array}$ & Week 16 fetal kidney & $\begin{array}{l}\text { Dropseq, Single-cell } \\
\text { RNA-seq }\end{array}$ & $\begin{array}{l}\text { Dynamic insight into early } \\
\text { processes of nephron } \\
\text { commitment in the } \\
\text { developing human; strong } \\
\text { congruence with the same } \\
\text { processes in mice }\end{array}$ & $\begin{array}{l}\text { Lindstrom } \\
\text { et al. 2018a }\end{array}$ \\
\hline $\begin{array}{l}\text { Human fetal } \\
\text { kidney }\end{array}$ & Weeks 7-25 fetal kidney & $\begin{array}{l}\text { STRT-seq, 3543/3023 after } \\
\text { QC cells }\end{array}$ & $\begin{array}{l}\text { Profile of the human fetal kidney } \\
\text { across time; identification of } \\
\text { cell type expression of genes } \\
\text { associated with renal disease }\end{array}$ & $\begin{array}{l}\text { (Wang et al. } \\
\text { 2018) }\end{array}$ \\
\hline $\begin{array}{l}\text { Human fetal } \\
\text { kidney }\end{array}$ & Weeks 9-18 fetal kidney & $\begin{array}{l}\text { Chromium 10x, single-cell } \\
\text { RNA-seq, 8205/6602 } \\
\text { after QC }\end{array}$ & $\begin{array}{l}\text { Profile of the developing kidney } \\
\text { focused on week 16, exploring } \\
\text { nephron progenitor } \\
\text { heterogeneity with } \\
\text { immunofluorescence and } \\
\text { single molecule fluorescent in } \\
\text { situ hybridization }\end{array}$ & $\begin{array}{l}\text { (Hochane } \\
\text { et al. 2019) }\end{array}$ \\
\hline Kidney organoids & Protocol/format & Transcriptional profiling & Analysis and conclusion & Reference \\
\hline $\begin{array}{l}\text { Whole organoids } \\
\text { across time }\end{array}$ & $\begin{array}{l}\text { Takasato protocol; total } \\
\text { organoids from day of } \\
\text { aggregation to day } 18\end{array}$ & Global RNA-seq & $\begin{array}{l}\text { Kidney organoids match } \\
\text { Trimester } 1 \text { human kidney. } \\
\text { Evidence for tubulogenesis, } \\
\text { patterning, and segmentation } \\
\text { across organoid culture }\end{array}$ & $\begin{array}{l}\text { Takasato et al. } \\
2015\end{array}$ \\
\hline Whole organoids & $\begin{array}{l}\text { Takasato vs. Morizane } \\
\text { protocols }\end{array}$ & Dropseq, ssRNA-seq & $\begin{array}{l}\text { Show cellular heterogeneity and } \\
\text { evidence of potential off target } \\
\text { populations; show variation in } \\
\text { patterning between the two } \\
\text { protocols }\end{array}$ & Wu et al. 2018 \\
\hline
\end{tabular}


Table 1. Continued

\begin{tabular}{|c|c|c|c|c|}
\hline $\begin{array}{l}\text { Human fetal } \\
\text { kidney }\end{array}$ & Age/stage & Transcriptional profiling & Analysis and conclusion & Reference \\
\hline $\begin{array}{l}\text { Whole organoids } \\
\text { from different } \\
\text { batches, } \\
\text { experiments, and } \\
\text { cell lines }\end{array}$ & $\begin{array}{l}\text { Takasato protocol; } \\
\text { differentiation time } \\
\text { course from } \\
\text { undifferentiated iPSC } \\
\text { through to mature kidney } \\
\text { organoids; includes } \\
\text { different cell lines and an } \\
\text { analysis of patient and } \\
\text { isogenic control.; includes } \\
\text { single cell and global } \\
\text { RNA-seq }\end{array}$ & $\begin{array}{l}\text { Global RNA-seq and } \\
\text { Chromium 10x, ssRNA- } \\
\text { seq; } 29 \text { organoid states; } \\
\text { two different iPSC lines; } \\
\text { >8000 cells }\end{array}$ & $\begin{array}{l}\text { Confirmed robustness and } \\
\text { reproducibility of protocol } \\
\text { between lines and batches; } \\
\text { identified technical variables, } \\
\text { relative nephron maturation, } \\
\text { and relative off-target } \\
\text { populations as greatest source } \\
\text { of variability; showed that } \\
\text { even isolated nephrons cluster } \\
\text { with whole organoids of the } \\
\text { equivalent day of } \\
\text { differentiation proposed } \\
\text { approach for normalization to } \\
\text { compare diseased and control } \\
\text { organoids }\end{array}$ & $\begin{array}{l}\text { Phipson et al. } \\
2019\end{array}$ \\
\hline $\begin{array}{l}\text { Whole well and } \\
\text { isolated } \\
\text { organoids }\end{array}$ & $\begin{array}{l}\text { Freedman protocol; isolated } \\
\text { from mesenchyme or } \\
\text { whole well }\end{array}$ & $\begin{array}{l}\text { Dropseq, ssRNA-seq; } \\
\quad>12,000 \text { cells }\end{array}$ & $\begin{array}{l}\text { Cell types present in organoids } \\
\text { recapitulate an anticipated } \\
\text { developmental trajectory; } \\
\text { reactivation of podocyte } \\
\text { development genes in } \\
\text { postnatal disease }\end{array}$ & $\begin{array}{l}\text { Harder et al. } \\
2019\end{array}$ \\
\hline Whole organoids & Takasato vs. Morizane & $\begin{array}{l}\text { Dropseq, ssRNA-seq; } 47 \\
\text { organoids states (includes } \\
\text { different stages of } \\
\text { differentiation); four } \\
\text { lines; } 382,000 \text { cells; also } \\
\text { profiled adult kidney } \\
\text { (>3000 cells) }\end{array}$ & $\begin{array}{l}\text { Confirm previously identified } \\
\text { cellular complexity, level of } \\
\text { maturation, and robustness of } \\
\text { protocol; congruence with } \\
\text { previously published } \\
\text { human fetal kidney data } \\
\text { (Lindstrom et al. 2018d; Young } \\
\text { et al. 2018); new data showing } \\
\text { that organoids after } \\
\text { transplantation show } \\
\text { diminished off-target } \\
\text { populations }\end{array}$ & $\begin{array}{l}\text { Subramanian } \\
\text { et al. } 2019\end{array}$ \\
\hline $\begin{array}{l}\text { Organoid } \\
\text { glomeruli and } \\
\text { organoid } \\
\text { podocytes }\end{array}$ & $\begin{array}{l}\text { Takasato; Sieved glomeruli, } \\
\text { isolated podocytes, and } \\
\text { whole organoids }\end{array}$ & Global RNA-seq & $\begin{array}{l}\text { Organoid glomeruli maintain a } \\
\text { superior transcriptional } \\
\text { identity in comparison with } \\
\text { organoid-derived podocytes } \\
\text { cultured in 2D or } \\
\text { immortalized podocyte lines; } \\
\text { isolated organoid glomeruli } \\
\text { can be used for modelling } \\
\text { podocytopathy or screening } \\
\text { compounds }\end{array}$ & $\begin{array}{l}\text { Hale et al. } \\
\quad 2018\end{array}$ \\
\hline $\begin{array}{l}\text { Bioprinted } \\
\text { organoids }\end{array}$ & Takasato protocol & Chromium 10x, ssRNAseq & $\begin{array}{l}\text { Cellular composition within } \\
\text { kidney organoids is the same } \\
\text { when generated using an } \\
\text { extrusion bioprinter compared } \\
\text { with manual aggregation }\end{array}$ & $\begin{array}{l}\text { Higgins et al. } \\
2018\end{array}$ \\
\hline Podocytes & New protocol & & & $\begin{array}{l}\text { Yoshimura } \\
\text { et al. } 2019\end{array}$ \\
\hline $\begin{array}{l}\text { Suspension culture } \\
\text { micro-organoids }\end{array}$ & Modified Takasato & Chromium 10x, ssRNA-seq & $\begin{array}{l}\text { Microorganoids show a cellular } \\
\text { complexity and transcriptional } \\
\text { profile similar to that of } \\
\text { kidney organoids grown on } \\
\text { Transwells. }\end{array}$ & $\begin{array}{l}\text { Kumar et al. } \\
2019\end{array}$ \\
\hline Whole organoids & $\begin{array}{l}\text { Takasato protocol compared } \\
\text { with human fetal kidney } \\
\text { (Lindstrom et al. 2018d) }\end{array}$ & Chromium 10x, ssRNA-seq & $\begin{array}{l}\text { Congruence between kidney } \\
\text { organoids and human fetal } \\
\text { kidneys }\end{array}$ & $\begin{array}{l}\text { Combes et al. } \\
2019 b\end{array}$ \\
\hline
\end{tabular}


and WNT9B, were not consistently detected. These markers are detected in whole-kidney bulk RNA-seq (Lindstrom et al. 2018c), but the cell type expression remains unclear. Further profiling of high-quality tissue samples at greater cell number and read depth will clarify local signaling environments and inform attempts to improve the specification, maintenance, and differentiation of human renal cell types.

Although nephron number is determined around birth, human and mouse kidneys continue to mature postnatally. An increase in the functional capacity of the postnatal kidney correlates with the maturation of the final burst of nephrons. Histological sections and single-cell profiling of developing (Adam et al. 2017; Magella et al. 2018; Park et al. 2018; Combes et al. 2019b) and adult mouse kidneys indicate a shift in the proportion of cell types from roughly equivalent numbers of stromal and epithelial cell types during development to an overrepresentation of nephron epithelium in the cortex of the adult kidney with a bias towards proximal tubule. Detailed microdissection studies from mature rat kidneys identified transcriptional profiles for 14 distinct nephron segments (Lee et al. 2015), whereas around seven have been identified during development in mouse (O'Brien and McMahon 2014). While there are known to be distinct molecular and metabolic changes in specific nephron cell types between development and adulthood as renal function increases after birth, these have not been thoroughly examined.

Understanding mammalian kidney development gives an insight into how renal cell types are specified and interact to form a functioning organ. Knowledge of these mechanisms informs attempts to recreate cell types and organs by approximating developmental programs in a dish. These endeavors depend on understanding cell type-specific gene expression patterns and the molecular mechanisms that regulate cell type specification, expansion and interaction.

\section{Building a kidney organoid from pluripotent stem cells}

The generation of pluripotent stem cell-derived organoids has become a major area of activity in the past decade. This has been an extension of earlier approaches to use an understanding of developmental principles to guide embryonic stem cells towards a specific lineage or cellular endpoint. Indeed, this was first demonstrated using mouse embryonic stem cells before the generation of the first human embryonic stem cell (Thomson et al. 1998) or induced pluripotent stem cell lines (Takahashi and Yamanaka 2006; Takahashi et al. 2007). The observation that in vitro differentiation protocols could recapitulate complex multicellular organotypic differentiation was really first evident in approaches in which 3D embryoid body culture was used to generate blood or myocardium (Doetschman et al. 1985; Keller et al. 1993). Embryoid body (EB) culture, in which an aggregate of undifferentiated embryonic stem cells was shown to spontaneously give rise to all three germ layers (Hirst et al. 2006), then became the starting point for many directed differentiation stud- ies. The standardization of cell number in such aggregates (spin EBs) (Ng et al. 2005) was used to differentiate to pancreas (Micallef et al. 2007) and blood (Ng et al. 2005) and the EB culture of human reporter lines for the MIXL1 transcription factor recapitulated gastrulation at the level of gene expression. The realization that complex models of developing tissues were arising in such cultures was perhaps most notably reported with the generation of human optic cup and pituitary organoids (Eiraku et al. 2008; Suga et al. 2011; Sasai 2013). However, reports of complex organotypic structures had previously been reported for pancreatic buds (Micallef et al. 2007) and intestine (Spence et al. 2011). Application of this type of approach was rapidly adopted to spectacular effect, with the formation of tissue as complex as the human cerebral cortex (Lancaster et al. 2013) and specific tailoring of differentiation protocols to generate the entire extent of the gastrointestinal tract from oesophagus to colon (McCracken et al. 2014, 2017; Múnera et al. 2017; Trisno et al. 2018). What is evident from all of these protocols is that the tissue generated is fetal in nature and that morphogenetic patterning is variable between organoids and even further between lines and individual experiments (Phipson et al. 2019). Hence, unlike the embryo itself, which can get it largely right every time, these are models with maturation and structural deficits. For obvious reasons, they are also limited in their capacity to reach endpoint differentiation or full scale by virtue of their in vitro unperfused state. In large part, these models are also lacking a neural and immune system, although some approaches are including such cellular components either as additional elements during differentiation (Schlieve et al. 2017) and/or transplantation for subsequent vascularization (Cortez et al. 2018; Daviaud et al. 2018).

In the kidney, the first evidence that progress was being made came with a series of publications in early 2014. Taguchi et al. (2014), working from mouse through to human, carefully defined a stepwise protocol for the generation of the metanephric mesenchyme (MM) (Taguchi et al. 2014). This mesenchyme could be induced to form nephrons comprising glomeruli attached to nephrons in response to a source of canonical Wnt signaling (Fig. 2; Taguchi et al. 2014). The resulting glomeruli would vascularize when transplanted under the renal capsule (Sharmin et al. 2016). At the same time, Takasato et al. (2014) reported a distinct stepwise approach initially using a MIXL1-GFP reporter ES cell line cultured in monolayer in which branching epithelial trees surrounded by epithelializing nephron progenitors were evident within 3 wk of commencing culture (Fig. 2). In this protocol, small kidney structures formed across the monolayer and while the formation of renal vesicles was observed, there were substantial areas of cells surrounding these structures that did not form kidney. In 2015, these approaches were followed by modified protocols that extended from pluripotency through to nephrogenesis with evidence for patterning and segmenting nephrons, sometimes accompanied by endothelial, perivascular, and seemingly appropriate stromal populations (Fig. 2; Freedman et al. 2015; Morizane et al. 2015; Takasato and Little 2015; Takasato 


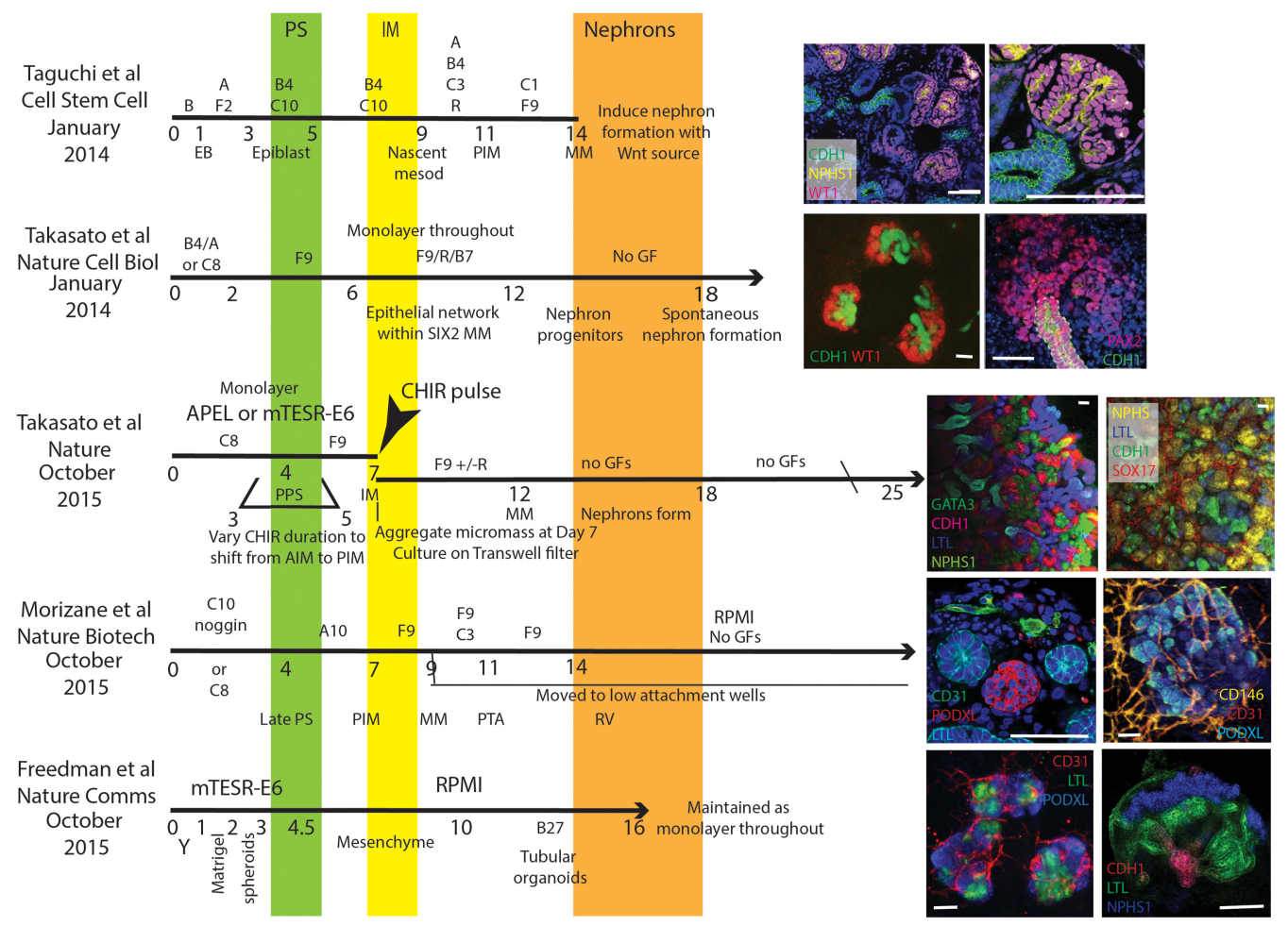

Figure 2. A comparison between the seminal protocols in the field for the directed differentiation of human pluripotent stem cells to kidney tissue, highlighting the congruence of timing between these approaches. Immunofluorescence images illustrate the presence of segmented nephrons in all instances. While the observation of a surrounding vasculature was highlighted in Takasato et al. (2015), the protocols of Taguchi et al. (2014) (R Nichinakamura, pers. comm.), Morizane et al. (2015) (as illustrated here), and Freedman et al. (2015) (as illustrated here) also show evidence of spontaneous endothelial cell formation. Factors and media used to direct differentiation: (A) Activin A (following number indicates micromolar concentration); (APEL) APEL differentiation medium (Stem Cell Technologies); (C) CHIR99201 (Wnt pathway agonist; following number indicates micromolar concentration); (B4) BMP4; (B7) BMP7; (B27) B-27 neural supplement medium; (F2) FGF2; (F9) FGF9; (no GFs) no growth factors added to basal medium; (mTESR-E6) E6 minimal differentiation medium (Stem Cell Technologies); (noggin) BMP antagonist; (R) retinoic acid, (RPMI) Roswell Park Memorial Institute 1640; (Y) Y27632 (Rho kinase inhibitor). Stages of differentiation: (AIM) Anterior intermediate mesoderm; (EB) embryoid body; (IM) intermediate mesoderm; (MM) metanephric mesenchyme; (PIM) posterior intermediate mesoderm; (PS) primitive streak; (PPS) posterior primitive streak; (PTA) pretubular aggregate; (RV) renal vesicle. Original figures are shown for the first two protocols (Takasato et al. 2014; Taguchi and Nishinakamura 2015). Reprinted with permission from Taguchi and Nishinakamura (2015) with permission from Elsevier. Unpublished images are presented for the final three protocols. Unpublished images were contributed by Lorna Hale (Takasato protocol), Tomoyo Miyoshi, Ryuji Morizane, Navin Gupta, Kimberley Homan and Jennifer Lewis (Morizane protocol), and Nelly Cruz (Freedman protocol). Scale bars, $50 \mu \mathrm{M}$.

et al. 2015). Morizane et al. (2015) induced aggregate formation in low-attachment wells. Freedman et al. (2015) plated in matrigel before monolayer culture with small nephroncontaining structures forming across the monolayer similar to that reported in Takasato et al. (2014). This group have subsequently mechanically loosened such structures allowing them to float in suspension and have reported that this culture format facilitates the formation of tubular cystic structures in an edited hPSC line into which homozygous mutations for PKD1 have been engineered (Table 2; Cruz et al. 2017). Takasato et al. (2015) formed a micromass aggregate at the stages of intermediate mesoderm, resulting in large kidney organoids with $~ 100$ interconnected nephrons surrounding stroma and vasculature (Fig. 2). In retrospect, there is evidence for the presence of an endothelial network in all of these protocols (Fig. 2; R Morizane, B Freedman, R Nishisnakamura, pers. comm.). While each protocol varied in culture conformation, all drew on an understanding of the growth factor signaling required across embryogenesis (Takasato and Little 2015) and all have subsequently been widely applied as organoid models of the human developing kidney (Fig. 2; Tables 1, 2). As a result, these approaches broadly use the same signaling pathways and arrive as similar stages of differentiation in a remarkably congruent time frame (Fig. 2).

While there have been other modifications or variations of these differentiation protocols published subsequently (Table 2), these four protocols (Taguchi et al. 2014; Freedman et al. 2015; Morizane et al. 2015; Takasato et al. 2015) have been the most widely adopted approaches for the generation of kidney tissue from human pluripotent stem cells (Tables 1,2) and the most comprehensive transcriptional analyses have been performed on the Takasato and Morizane protocols in particular (Takasato et al. 2015; 
Downloaded from genesdev.cshlp.org on April 26, 2023 - Published by Cold Spring Harbor Laboratory Press

Table 2. Modifications to kidney organoid culture format to address specific applications

\begin{tabular}{|c|c|c|c|c|}
\hline Change to culture / format & Reference & Endpoint & $\begin{array}{l}\text { Potential application } \\
\text { /advance }\end{array}$ & $\begin{array}{l}\text { Differentiation } \\
\text { protocol }\end{array}$ \\
\hline \multirow{3}{*}{ Suspension culture } & Cruz et al, 2017 & Organoid derived tubular cyst & Disease modelling & Adaptation of Freedman 2015 \\
\hline & Przepiorski et al, 2018 & $\begin{array}{l}\text { Organoids from EBs } \\
\text { cultured in suspension }\end{array}$ & $\begin{array}{l}\text { Scale up of cells } \\
\text { Toxicity screening } \\
\text { Disease modelling }\end{array}$ & Adaptation of Takasato 2015 \\
\hline & Kumar et al, 2019 & $\begin{array}{l}\text { Micro-organoids in formed } \\
\text { in suspension culture }\end{array}$ & $\begin{array}{l}\text { Scale up of cells } \\
\text { Drug screening } \\
\end{array}$ & Adaptation of Takasato 2015 \\
\hline \multirow{2}{*}{ Higgins et al, 2018} & Czerniecki et al, 2018 & $\begin{array}{l}\text { Differentiation in multiwell format after } \\
\text { plating using liquid handling robot }\end{array}$ & $\begin{array}{l}\text { Optimatisation of differentiation } \\
\text { High content screening }\end{array}$ & Adaptation of Freedman 2015 \\
\hline & Higgins et al, 2018 & $\begin{array}{l}\text { Extrusion bioprinting of day } 7 \mathrm{IM} \\
\text { to automate generation of organoids }\end{array}$ & $\begin{array}{l}\text { Disease modelling } \\
\text { Increased throughput } \\
\text { Drug / toxicity screening } \\
\text { Improved quality control } \\
\end{array}$ & Adaptation of Takasato 2015 \\
\hline \multirow{3}{*}{$\begin{array}{l}\text { New iPSC-derived structures } \\
\text { Taguchiet al,2017 - Leuning et al, 2018 } \\
\text { Isolated features / cell types }\end{array}$} & Taguchi et al, 2017 & $\begin{array}{l}\text { Combined culture of NPC and } \\
\text { CD to form more complex kidney }\end{array}$ & $\begin{array}{l}\text { Improved developmental model } \\
\text { Tissue replacement }\end{array}$ & New protocol \\
\hline & Leuning et al, 2018 & $\begin{array}{l}\text { Revascularisation of human kidney } \\
\text { scaffold with iPSC-derived endothelium }\end{array}$ & Tissue replacement & Orlova et al, 2014 \\
\hline & Musah et al, 2017 & Directed differentiation to podocytes & $\begin{array}{l}\text { Toxicity screening } \\
\text { Disease modelling } \\
\end{array}$ & New protocol \\
\hline \multirow{3}{*}{ 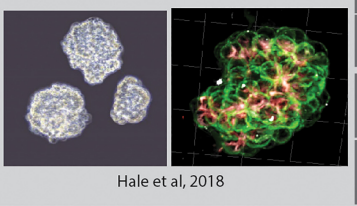 } & Yoshimura et al, 2018 & Directed differentiation to podocytes & $\begin{array}{l}\text { Disease modelling } \\
\text { Drug / toxicity screening }\end{array}$ & Adaptation of Taguchi 2014 \\
\hline & Taguchi et al, 2017 & $\begin{array}{l}\text { Optimatisation of collecting } \\
\text { duct differentiation }\end{array}$ & $\begin{array}{l}\text { Improved developmental model } \\
\text { Tissue replacement }\end{array}$ & New protocol \\
\hline & Hale et al, 2018 & $\begin{array}{l}\text { Isolation of intact glomeruli } \\
\text { from organoids }\end{array}$ & $\begin{array}{l}\text { Disease modelling } \\
\text { Drug / toxicity screening }\end{array}$ & Adaptation of Takasato 2015 \\
\hline \multicolumn{5}{|c|}{ Changes in scaffolds for culture } \\
\hline & Gupta et al, 2019 & Scaffolding organoids on silk & Scale up of structure & Adaptation of Morizane 2015 \\
\hline & Garreta et al, 2019 & Differentiation on hydrogels & Improved maturation & Adaptation of Takasato 2015 \\
\hline \multirow{2}{*}{ Application of flow in vitro } & Musah et al, 2017 & $\begin{array}{l}\text { Glomerulus on chip / } \\
\text { co-culture with endothelium }\end{array}$ & $\begin{array}{l}\text { Disease modelling } \\
\text { Drug / toxicity screening }\end{array}$ & New differentiation protocol \\
\hline & Homan et al, 2019 & $\begin{array}{l}\text { Organoid culture within } \\
\text { PDMS chamber with flow }\end{array}$ & $\begin{array}{l}\text { Improved developmental model } \\
\text { Functional maturation }\end{array}$ & Adaptation of Morizane 2015 \\
\hline \multicolumn{5}{|c|}{ Transplantation for vascularisation } \\
\hline \multirow{6}{*}{ van den Berg et al, 2018 } & Garreta et al, 2019 & Culture on chicken CAM & $\begin{array}{l}\text { Functional maturation } \\
\text { Vascularization }\end{array}$ & Adaptation of Takasato 2015 \\
\hline & Sharmin et al, 2016 & $\begin{array}{l}\text { Renal subcapsular } \\
\text { transplantation }\end{array}$ & Vascularization & Taguchi et al, 2014 \\
\hline & Bantounas et al, 2018 & Subcutaneous transplantation & Vascularization & Adaptation of Takasato 2015 \\
\hline & Van den Berg et al, 2018 & $\begin{array}{l}\text { Renal subcapsular } \\
\text { transplantation }\end{array}$ & $\begin{array}{l}\text { Vascularization } \\
\text { Functional maturation }\end{array}$ & Adaptation of Takasato 2015 \\
\hline & Tanigawa et al, 2018 & $\begin{array}{l}\text { Renal subcapsular } \\
\text { transplantation }\end{array}$ & Disease modelling & Adaptation of Taguchi 2014 \\
\hline & Gupta et al, 2019 & $\begin{array}{l}\text { Renal subcapsular } \\
\text { transplantation }\end{array}$ & Vascularization & Adaptation of Morizane 2015 \\
\hline
\end{tabular}

Wu et al. 2018; Combes et al. 2019b; Phipson et al. 2019; Subramanian et al. 2019|. We focus on our own protocol (Takasato et al. 2015, 2016) to illustrate how kidney organoid differentiation is performed and how we have validated the identity of component cell types within these structures. The Takasato approach involves the directed differentiation of human pluripotent stem cells, including either embryonic stem cells or induced pluripotent stem cells, as a monolayer subjected to an initial patterning to posterior primitive streak by virtue of the addition of either a canonical Wnt agonist or specific ratio of BMP4/ Activin A, followed by induction of intermediate mesoderm via the addition of FGF9 (Fig. 2). In our original protocol (Takasato et al. 2014), cultures spontaneously formed self-organizing structures comprised of a $\mathrm{PAX}^{+}$
$\mathrm{CDH}^{+}$branching epithelium, described as ureteric epithelium, surrounded by a $\mathrm{WT}^{+}$mesenchyme that was undergoing a mesenchyme to epithelial transition to form renal vesicle structures, as evidenced by staining for CDH6 and JAG1. While this was the first report of a self-organizing kidney-like structure, these arose sporadically across the tissue culture dish and did not appear to make well-patterned nephrons. By examining the duration of the initial Wnt signaling, we subsequently showed that prolongation of the addition of CHIR shifted the population from a more $\mathrm{GATA} 3^{+}$anterior intermediate mesoderm to a more HOXD $11^{+}$posterior mesoderm, presumably favoring nephron formation (Takasato et al. 2015). In addition, the protocol was altered to dissociate the cultures after day 7 and form an aggregate of cells 
$\left(5 \times 10^{5}\right.$ cells per aggregate $)$ that was placed on a Transwell filter and subsequently subjected to culture at an air-media interface (Figs. 2, 3). This approach was chosen to provide a more $3 \mathrm{D}$ environment within which the cells could self-organize and represents the approach that had classically been used to culture mouse embryonic kidneys for $>50 \mathrm{yr}$ (Saxen 1987). Indeed, the capacity for an embryonic kidney to self-organize into an appropriate structure post dissociation to single cell had been demonstrated previously (Lusis et al. 2010; Unbekandt and Davies 2010; Hendry et al. 2013; Lefevre et al. 2017). As a result of this change in protocol, we were able to form organoids that contained a connected epithelial network to which were attached patterning, segmenting, and elongating epithelial structure recognizable as early nephrons (Fig. 3AE). Each organoid contained $\sim 100$ nephrons and reached a diameter of $\sim 4$ to $8 \mathrm{~mm}$ within $18 \mathrm{~d}$ of culture postaggregation (Fig. 3A,C). There was a central epithelial network connecting the presumptive nephrons that was positive for PAX2, CDH1, GATA3, LHX1, and KRT8 proteins (Fig. 3A,B,E) and stained with the collecting duct specific-lectin, Dolichos biflorus (DBA) (Takasato et al. 2015). As such, we described this as a ureteric epithelium/ collecting duct network. Within the forming nephrons, antibody staining showed evidence of a proximal nephron population positive for WT1, MAFB, and NPHS1, all proteins that ultimately mark the podocytes of the glomerulus (Fig. 3E-G). Between these regions was an EPCAM ${ }^{+}$ $\mathrm{CDH}^{-}$epithelium identified as proximal tubule due to positive staining for CUBN, LRP2, HNF4A, and Lotus tetragonolobus lectin (LTL) (Fig. 3E,J,K) and an EPCAM $^{+}$ $\mathrm{CDH}^{+}$epithelium identified as distal tubule (Fig. 3E). By day 25 of culture (18 d after plating on Transwell filters), this medial segment showed staining for UMOD suggesting the formation of a presumptive loop of Henle (Fig. 3A,B,E). Around the forming nephrons was a MEIS1 ${ }^{+}$stroma (Fig. 3E), a KDR $1^{+} \mathrm{SOX} 17^{+} \mathrm{CD} 31^{+}$endothelial plexus (Fig. 3C-E), and some evidence for a PDGFRA ${ }^{+}$ pericyte population alongside this (Takasato et al. 2015). Hence, these kidney organoids showed substantial cellular complexity, including the spontaneous formation of nephrons within a stroma that also contained a vasculature. The presence of a ureteric epithelium, distal nephron segments, and a clear vasculature and perivascular population suggested that this protocol represented the most complex kidney organoid protocol described to date. However, as noted above, re-examination of the other protocols also shows evidence of endothelium and more extensive evidence of nephron segmentation (Fig. 2 ). Hence, the published protocols generate similar structures with structural differences primarily reflecting varying culture format.

\section{Characterizing the renal cell types evident within kidney organoids}

Kidney organoids are recognizable as kidney due to the presence of patterning and segmenting nephrons that display an appropriate morphology and segment-specific pro- tein staining. Both global profiling and characterization of individual cellular components is helping us to understand the developmental accuracy and relative maturity of component cell types compared with existing immortalized human cell lines. Perhaps the cell type most thoroughly characterized to date are the glomerular epithelial cells or podocytes of the nephrons (Fig. 3F-H). Initially examined via microarray profiling of human kidney organoids generated using the Taguchi protocol (Sharmin et al. 2016), these have more recently been analyzed after both FACS sorting, primary 2D culture (OrgPods), and in intact isolated 3D organoid glomeruli (OrgGloms) via RNAseq (Hale et al. 2018). While freshly isolated OrgPods cultured in $2 \mathrm{D}$ showed an appropriate podocyte morphology, protein expression and response to insulin, as previously demonstrated using human immortalized podocyte cell lines, the presence of polarized slit diaphragm proteins (Fig. 3F), and improved expression of podocyte-specific genes (Fig. 3H) was seen in the 3D OrgGloms (Hale et al. 2018). Indeed, proteomic analysis showed a more mature matrisome in $3 \mathrm{D}$ than $2 \mathrm{D}$ with evidence for appropriate collagen and laminin switching. The colocalization of slit diaphragm proteins has also been reported using the Freedman (Kim et al. 2017) and Taguchi (Tanigawa et al. 2018) protocols. Indeed, most recently Yoshimura et al. (2019) modified their directed differentiation protocol to maximize the formation of podocytes at the expense of other kidney cell types. This involved inhibition of both Wnt and TGF $\beta$ signaling to proximalize the forming renal vesicle epithelium, resulting in a layer of $>90 \%$ podocyte (Yoshimura et al. 2019). Such studies suggest that the level of podocyte identity present in the glomeruli of organoids is superior to any previous model of this complex and structurally constrained cell type. Indeed, using induced pluripotent stem cell lines from congenital nephrotic syndrome patients carrying distinct point mutations in NPHS1, both Tanigawa et al. (2018) and Hale et al. (2018) show that the resulting organoid glomeruli display podocyte defects consistent with the patient phenotype. This is a powerful proof of concept for disease modeling using organoids.

The individual characterization of human renal cell types within organoids is being assisted via the development of fluorescent reporter tools generated using CRISPR/Cas9 gene editing (Sharmin et al. 2016; Boreström et al. 2018; Hale et al. 2018; Howden et al. 2018; van den Berg et al. 2018; Vanslambrouck et al. 2019|. By targeting fluorescent reporter proteins to the loci of cell type-specific genes, it has been possible to visualize these cell types within the organoids in vitro (Sharmin et al. 2016; Boreström et al. 2018) and in vivo after transplantation (van den Berg et al. 2018) as well as isolate and characterize individual cell types from within organoids using fluorescence activated cell sorting (Fig. 3I-N; Vanslambrouck et al. 2019). This approach was applied for the temporal transcriptional analysis of the maturing glomerulus using a MAFBmTAGBFP reporter line that marks the forming podocytes (Fig. 3M; Hale et al. 2018) and has been shown recently to effectively enrich for a variety of cell types from within complex organoids, including 

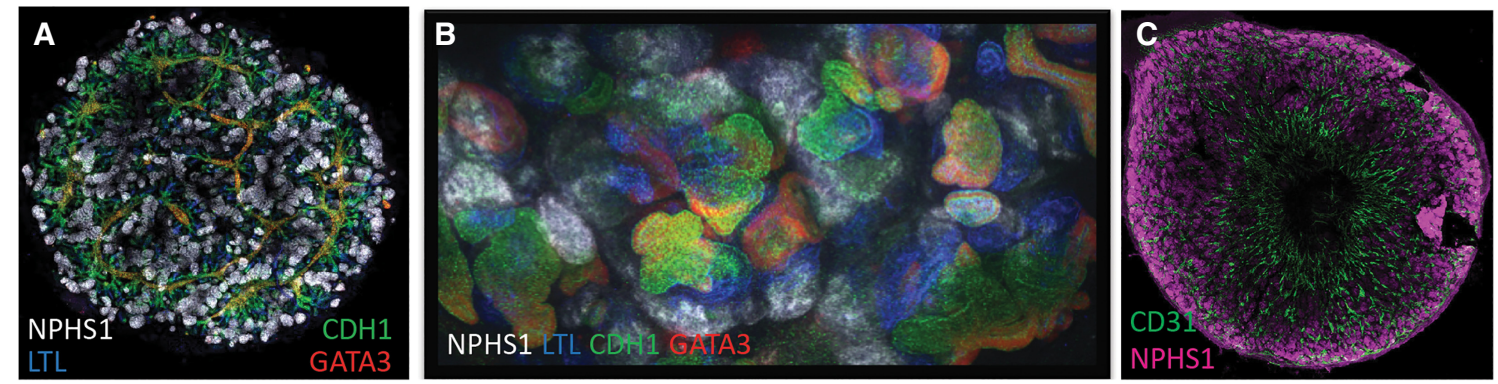

D

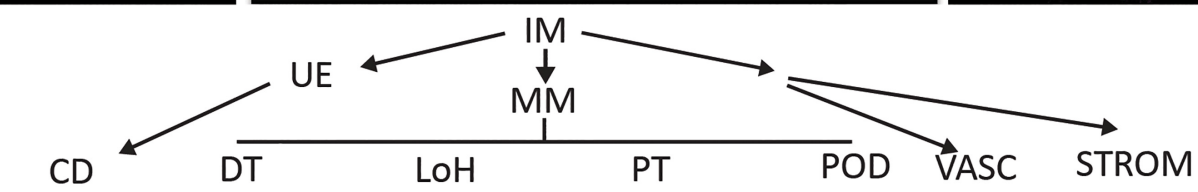

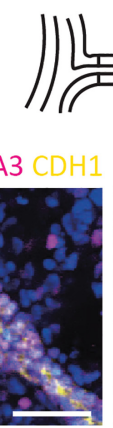

Collecting duct

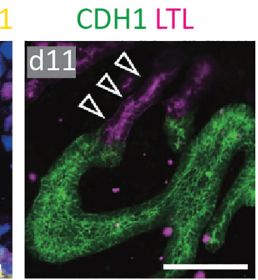

Segmented nephron

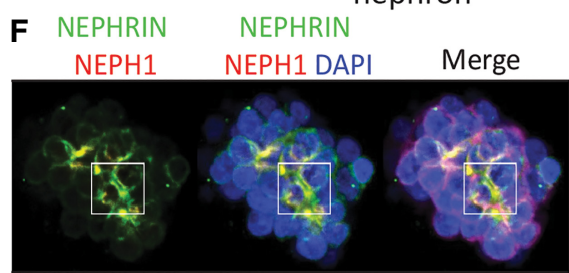

G
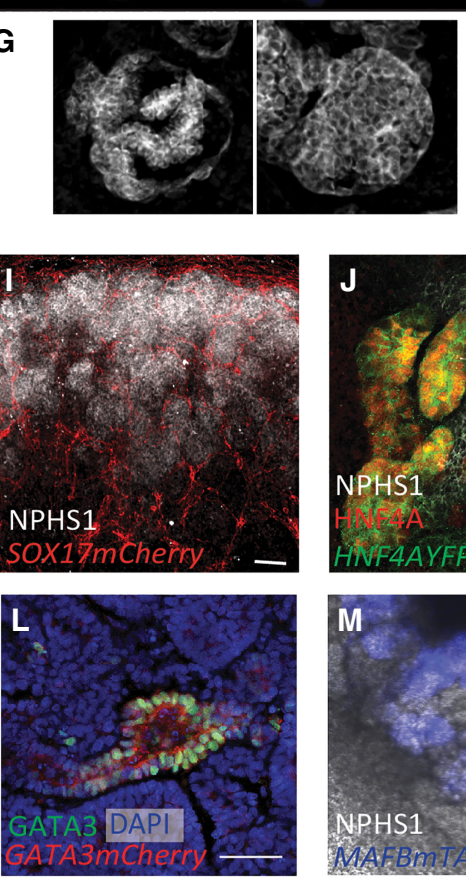
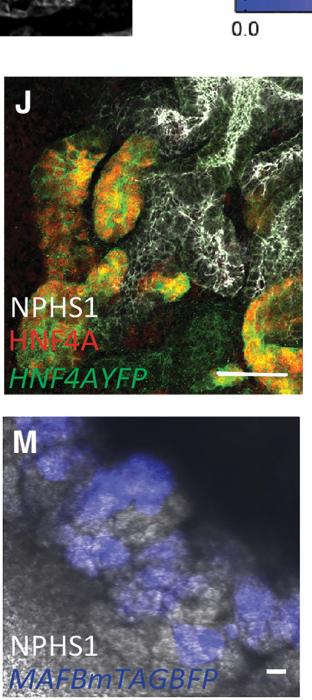

CDH1 UMOD

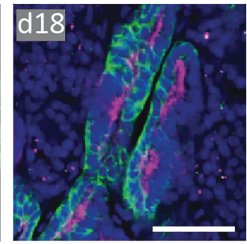

Loop of Henle

H

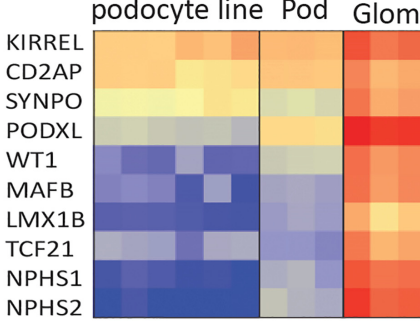

NPHS2
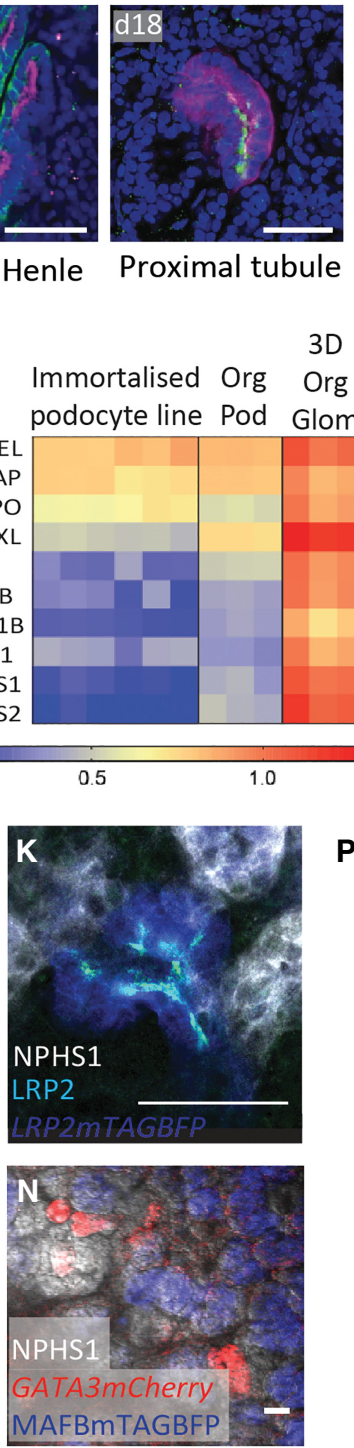

Proximal tubule

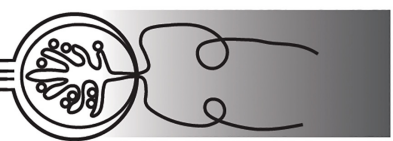

CD31 NPHS1

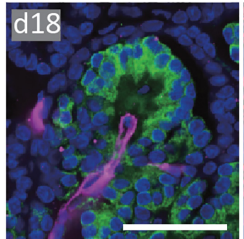

Podocytes \& Vasculature

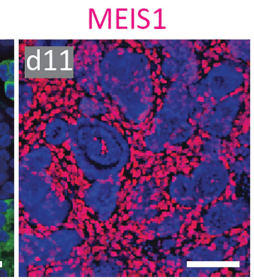

Stroma

0

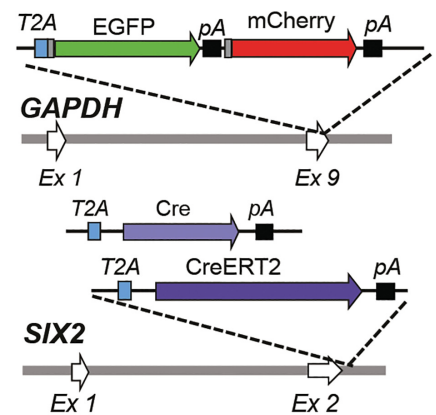

EPCAM LTL NPHS1 mCherry

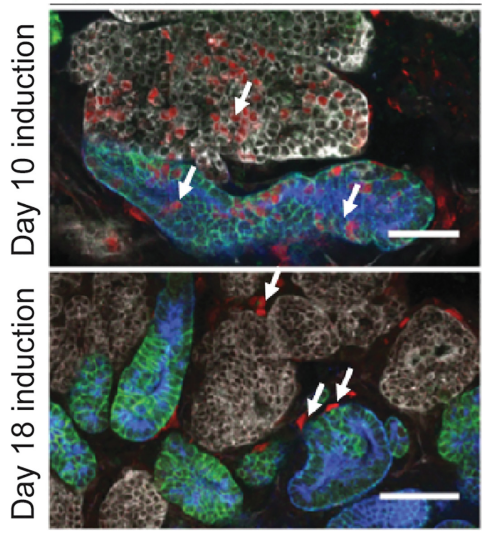

Figure 3. See legend on following page. 
endothelium, nephron progenitor, proximal tubule, and distal tubule (Fig. 3I-N; Vanslambrouck et al. 2019). The generation of fluorescent single and double fluorophore reporter lines (Fig. $3 \mathrm{~N}$ ) will also allow time-lapse imaging of morphogenesis, facilitating an analysis of nephron formation within kidney organoids. This should identify how nephron segmentation is occurring in vitro and potentially enlightening about developmental processes never observed in human development. Alternatively, such analyses may identify problems with the appropriate induction of segment-specific transcription factors, thereby ultimately leading to optimization of the differentiation protocols. Finally, reporter lines are now allowing the dissection of lineage relationships in the human system (Fig. 3OP). Indeed, we have now definitively shown that the nephron epithelium arising in our kidney organoids comes from a SIX2-expressing nephron progenitor, as anticipated based upon our understanding of nephron formation in the mouse (Fig. 3OP; Howden et al. 2019).

\section{The balance between reproducibility and cellular complexity}

With these advances has come an extraordinary level of interest in kidney organoids. Indeed, the development of protocols for generating kidney organoids has been a disruptive technology in both developmental biology and experimental nephrology. The utility of such methods will require developmental accuracy, but will also need to be highly reproducible and applicable to any cell line. Like the developing kidney itself, kidney organoids contain multiple distinct cell types. This level of cellular complexity, while accurately generated during normal em- bryogenesis, represents a technical challenge. Indeed, this is a challenge for any complex multicellular pluripotent stem cell-derived organoid model. While a coronal section of an embryonic mouse brain will be anatomically equivalent to the same section taken from any normal mouse of that given strain and developmental age, a cerebral organoid can show considerable anatomical variation between organoids with variable numbers of ventricles, presence or absence of eye tissue and variable contribution of tissue representing other brain regions (Lancaster et al. 2013; Camp et al. 2015). An embryonic mouse also has an anatomically reliable clock such that it is easy to ensure that embryos of the same stage of development are being compared with each other. This is much less easy to control in an organoid culture. For kidney organoids to surpass the use of animal models, the protocols must be highly reproducible and transferable between distinct starting cell lines.

Transcriptional profiling has first allowed us to better understand the cellular complexity of kidney organoid models but also to begin to examine the robustness of the differentiation protocols and the sources of technical variability. Using single-cell RNA-seq, Wu et al. (2018) directly compared the temporal transcriptional changes across differentiation and the cellular complexity of both the Morizane et al. (2015) and Takasato et al. (2015) kidney organoid protocols. They concluded that protocol-based differences in the relative nephron segments and potential off-target populations present existed between these two protocols, noting that both contained substantial stromal populations that were not readily identified based on our understanding of mouse kidney development. Kidney organoids generated using the Morizane protocol showed lower rates of cellular proliferation

Figure 3. Cellular complexity of kidney organoids generated via directed differentiation of human pluripotent stem cells using the Takasato protocol. $(A-C)$ Human kidney organoids generated using Takasato et al. (2015) at day 25 of culture. $(A, B)$ Immunofluorescence staining of whole kidney organoid $(A$; diameter $=3 \mathrm{~mm})$ and higher magnification $(B)$ shows evidence for glomeruli (NPHS1; white), proximal tubules (LTL; blue), distal tubules (CDH1; green), and a connecting epithelial network positive for GATA3 (red) and CDH1 (green). (C) Evidence of an extensive endothelial network (CD31; green) between organoid glomeruli (NPHS1; magenta). (D) Diagram of kidney differentiation from the intermediate mesoderm (IM) highlighting the ureteric epithelium (UE) as the origin of the collecting duct and the metanephric mesenchyme (MM) as the origin of the nephron. Evidence exists for stromal and vascular progenitors; however, their origins are less clear. (DT) Distal tubule; (LoH) loop of Henle; (PT) proximal tubule; (POD) podocyte; (VASC) vasculature; (STROM) stroma. (E) Immunofluorescence images of the cellular elements present within a kidney organoid generated using Takasato et al. (2015). (F) Immunofluorescence analysis of isolated organoid glomeruli showing polarized colocalization of the slit diaphragm proteins NEPHRIN (green) and NEPH1 (red) proteins compared with the nonpolarized protein PODXL (magenta). Image from Hale et al. (2018). (G) Bright-field image through intact organoid glomeruli with capillary loop structure evident at the left. Image from Hale et al. (2018). (H) Heat map showing relative expression of key podocyte genes in the immortalized podocyte cell line compared with organoid derived podocytes (OrgPod) after 2D culture and 3D isolated organoid glomeruli (OrgGlom). Adapted from Hale et al. (2018). (I-N) Reporter lines illustrating the presence of individual cell types within kidney organoids. In each example, the promoter into which the fluorescent reporter has been placed is indicated in italics while regular text is used for antibody staining. These reporters demonstrate the presence of endothelial cells $(I$, Sox $17 \mathrm{~m}$ Cherry) (Ng et al. 2016), proximal tubules (J, HNF4AYFP; $K$, Lrp2mTAGBFP), connecting segment/ureteric epithelium (L, GATA3mCherrry), podocytes (M, MAFBmTAGBFP), and a double reporter with both GATA3mCherry and MAFBmTAGBFP (N). Images from Vanslambrouck et al. (2019). (O) Targeting constructs for the generation of a human iPSC SIX2 lineage tracing reporter line. Tamoxifen (4-OHT) will result in the production of Cre recombinase within any cell expressing SIX2. As a result, loxP-Cre mediated excision of the EGFP cassette present within the GAPDH safe harbor locus will cause a switch in cell color from green to red (mCherry). Howden et al. (2019). ( $P$ ) High-resolution immunofluorescence of nephrons within kidney organoids subjected to early (day $7+10)$ or date $($ day $7+18)$ 4-OHT. mCherry indicates cells that have initiated SIX2 expression. mCherry ${ }^{+}$cells within nephrons after early induction shows that a SIX2-expressing progenitor contributes to nephron formation early in organoid patterning. The absence of mCherry within nephrons after late induction shows that this is no longer the case at later time points. Glomeruli (NPHS1; white), proximal tubules (LTL; blue), nephron epithelium (EpCAM; green). Adapted from Howden et al. (2019). Scale bars, $50 \mu M$. 
and potentially greater maturation of component cell types. They went on to map the expression of genes previously associated with kidney disease, suggesting significant potential for kidney organoids to recapitulate such transcriptional networks. A much larger single cell study $(440,000$ single cells) comparing the same two protocols is now available as preprint (Subramanian et al. 2019) and similarly concluded that kidney organoids contain cell clusters recognizable as anticipated cell types within the developing kidney. They also concluded that the protocols are robust and reproducible by comparing different cell lines differentiated using the same methods (Subramanian et al. 2019). More recently, organoids generated using the Freedman protocol (Freedman et al. 2015) have been analyzed identifying the expression of podocyte genes known to be associated with glomerular disease (Harder et al. 2019).

Using global organoid RNA-seq, we have more formally examined the sources of variation in organoids generated using the Takasato protocol between cell line, individual organoid, and individual experimental batch across time (Phipson et al. 2019). The reproducibility of the differentiation protocol between lines was confirmed (Fig. 4A). Not surprisingly, however, this analysis identified technical issues, such as batch, as a major source of global transcriptional variation. The most variable genes between experimental batch included genes which increase in expression with nephron tubulogenesis, suggesting that distinct lines and experiments were slightly more or less differentiated than their comparator. This may reflect batch-to-batch variations in growth factors, cell density, or line-specific differences in rates of proliferation, but highlights the challenge of accurately identifying genuinely disease-related transcriptional changes between patient and control lines. In the same study, an analysis of organoids at the single-cell level again showed tight congruence between organoids particularly within a single batch (Fig. 4B), but illustrated shifts in relative component cell types, including relative nephron maturation and offtarget populations, as contributing to batch to batch variation. A tightening of the differentiation parameters and consideration of experimental design needs to be guided by such observations. Indeed, in a study comparing the transcriptional profile of magnetically sorted epithelium from kidney organoids generated from a nephronophthisis patient-derived iPSC and a CRISPR/Cas9 gene corrected iPSC line, normalization for highly variable genes revealed a clear defect in epithelial polarization that was confirmed in matrigel culture (Forbes et al. 2018).

\section{Examining the transcriptional congruence between kidney organoids and the human fetal kidney}

Having established the robustness, transferability and cellular complexity of kidney organoids, how well do these structures really model the normal processes of kidney morphogenesis and will a model of a developing human kidney, no matter how accurate, be of clinical value? Morphologically, the early nephrons in these kidney organoids appear to pattern in a similar fashion to what might be expected based on our understanding of kidney morphogenesis in mouse and human. There is also a global transcriptional congruence evident between kidney organoids and Trimester 1 human kidney, which exceeds that with other human fetal tissues (Takasato et al. 2015). With the recent increasing access to single-cell transcriptional data from the human fetal kidney, it has also been possible to begin to directly compare organoid and fetal kidney tissue.

Cell types within kidney organoids were initially defined based on morphology and expression of established markers of mouse renal cell types by immunofluorescence. The application of single-cell profiling has enabled a deeper analysis of kidney organoid cell types, dramatically expanding the complement of markers used to identify organoid renal cell types and identifying varying proportions of off-target neural, glial, muscle progenitor, and melanocyte populations (Wu et al. 2018; Combes et al. 2019b; Harder et al. 2019; Howden et al. 2019; Subramanian et al. 2019). Pseudotime analysis of organoid nephron cell types suggests that organoid nephron formation replicates the expected trajectory from nephron progenitor to podocyte and tubular endpoints /Combes et al. 2019b). Despite the expression of key cell type markers in kidney organoids, the possibility of deeper underlying differences between organoid nephron, stromal, and endothelial cell types and those from the human fetal kidney remained. To address this we performed an integrated analysis of single cell profiles from human kidney organoids with cells from the human fetal kidney cortex (Lindstrom et al. 2018b). Clusters in the combined data set contained cells from organoids and human fetal kidney with transcriptional congruence for cell type-specific markers of stromal, nephron, and endothelial cell types (Fig. 4CD; Combes et al. 2019b). The relative proportions of stromal, nephron, endothelial and other cell types were comparable between the data sets (Fig. 4E). Other comparisons of organoid and human kidney cell types have found similar conservation (Wu et al. 2018; Harder et al. 2019). Our understanding of stromal populations in the human fetal kidney is limited. However, human fetal kidney data sampled from the renal cortex contained five populations within three major groups (Lindstrom et al. 2018b). These populations appeared to be conserved to some extent in kidney organoids with human fetal kidney and organoid cells substantially contributing to three combined stromal clusters (C0-C2) (Fig. 4C). Analysis of genes conserved between human fetal kidney and organoid cells within these clusters identified conservation of renal stromal markers including TAGLN, PDGFRA, DCN, MGP, $P D G F R B$, and many more. However, established markers of the nephrogenic zone stroma such as FOXD1 and $P B X 1$ were not detected in either the organoid or human fetal kidney cells, despite these genes being present in bulk RNA sequencing data sets for both tissue types (Lindstrom et al. 2018c; Phipson et al. 2019). Likewise, insight into signaling pathway components expected to play analogous roles in mouse and human was limited. Failing to detect established marker genes sustains the possibility 
A

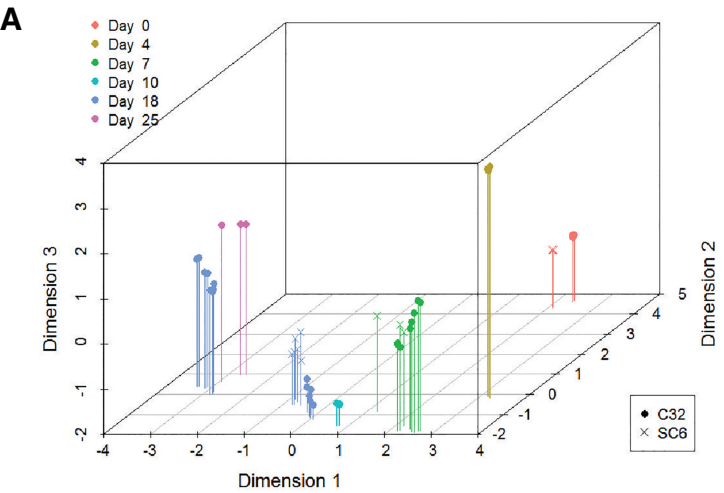

$\mathbf{C}_{5}$

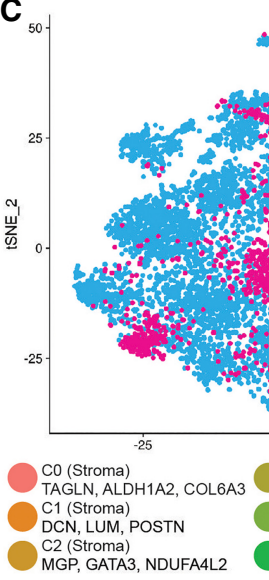

$\mathbf{F}$

a

D

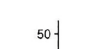

B

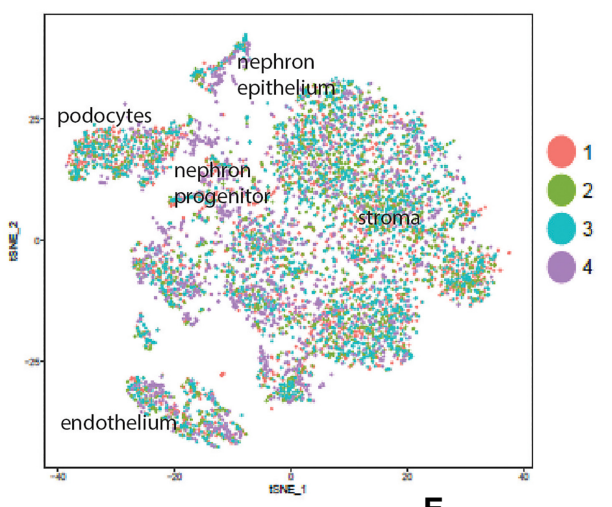

E
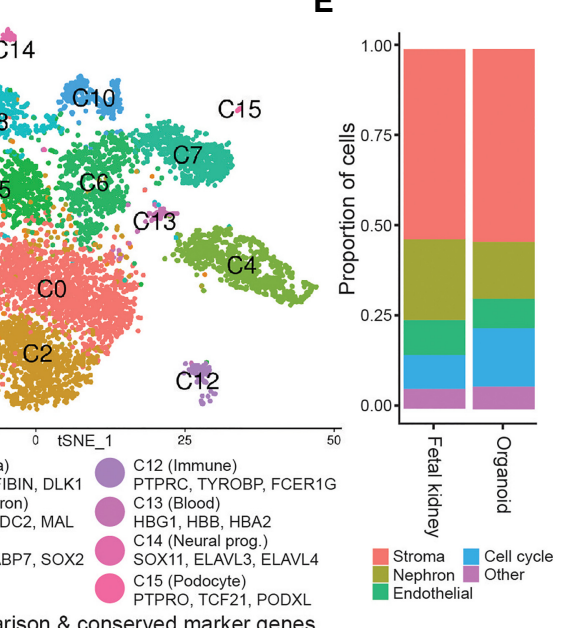

Identity $\mathrm{Jl}$ Comparison \& conserved marker genes C9 Stroma
C3 Stroma
C2 Stroma
C1 Stroma
c0 Stroma (O7) COL9A3, FIBN, DLK1 (O1) CTSK, DNM3OS, LIMA1 (O3) MGP, GATA3, NDUFA4L2 (O0) DCN, LUM, POSTN (O0) TAGLN, ALDH1A2, COL6A3

Figure 4. Investigating the reproducibility, cellular complexity, transcriptional and developmental accuracy of hPSC-derived kidney organoids. (A) 3D correlation analysis of global transcriptional profile across kidney organoid differentiation from day 0 (undifferentiated iPSC) through day 4 (posterior primitive streak), day 7 (intermediate mesoderm) and days 10, 18, and 25 of organoid culture using two distinct iPSC lines. This analysis suggests that the differentiation protocol is robust with replicates correlating with stage of differentiation even when generated using different iPSC lines and experiments performed at different times. From Phipson et al. (2019). (B) tSNE plot showing overlay of $>8000$ single cells generated from four different day $7+18$ kidney organoids showing strong reproducibility between organoids at the single-cell level. From Phipson et al. (2019). (C) tSNE plot overlaying single cells isolated from iPSC-derived kidney organoids (blue) with human fetal kidney (pink). Reprinted from Combes et al. (2019b). (D) Analysis of the cell types present in the human fetal kidney and organoid data sets, as analyzed in Combes et al. (2019b). (E) Relative abundance of key cellular elements in human fetal kidney versus kidney organoid. Note that while stroma is a prevalent component in kidney organoids, this is also the case in human fetal kidney. Kidney organoids showed a higher level of proliferating cells (cell cycle). Reprinted from Combes et al. (2019b). (F) Comparison of organoid cell clustering in "organoid only" to "combined" organoid and human fetal kidney clusters. Overlap in samples within clusters from the different analyses is shown using the Jaccard Index (JI) with a score of 1 (yellow) indicating identical clusters and 0 (blue) indicating no cells in common. Combined (C) cluster identities are listed at the left of the heat map indicating JI score, some markers conserved between organoid and fetal kidney cells within each cluster are listed at the right.

of important differences between cell types in organoids and human fetal kidney that may only be revealed by comparison of improved data sets. Despite the absence of some expected markers there is a high level of congruence in how kidney organoid cell types cluster in isolation or combined with human fetal kidney, again supporting congruence between key renal cell types from both tissue types (Fig. 4F).

\section{Accurate lineage but precocious cessation of nephrogenesis within organoids}

The described transcriptional analyses of organoids supports their molecular relevance as a model of human nephrogenesis; however, it says little about morphology. As described above, ongoing nephrogenesis within the developing mouse kidney is driven via the reciprocal 
interactions between the ureteric tip and the surrounding nephron progenitor population, the $\mathrm{SIX}^{+}$cap mesenchyme. A premature commitment of the nephron progenitor population to nephron formation results in hypoplasia as both branching and nephrogenesis cease (Self et al. 2006). Does a nephron progenitor population exist in kidney organoids and is there ongoing nephron formation? What is not evident in any of hPSC-derived kidney organoids described above is a branching ureteric tree with tips surrounded by cap mesenchyme. However, nephrons are clearly forming. We have recently begun to look into the lineage relationships of the cells present within our kidney organoids to tease these questions apart. Using a unique lineage reporter system involving the homozygous targeting of a loxP-GFP-loxP-mCherry cassette into the GAPDH safe harbour locus and Cre recombinase into the SIX2 locus, it has been possible to show that the epithelial cells of kidney organoid nephrons do indeed arise from a SIX2-expressing population, as would be anticipated based upon the mouse (Howden et al. 2019). Important$1 y$, there was no evidence that this cell type gave rise to the endothelial population within organoids, suggesting a distinct lineage relationship between nephron epithelium and other organoid cell types (Howden et al. 2019). By retargeting the SIX2 locus with CreERT2 (Fig. 3O), it was also possible to determine whether there is evidence for continued nephron formation from such a progenitor population across time in an organoid by controlling the timing and dose of tamoxifen (Fig. 3P). Induction of Cre recombinase at day 10 of culture resulted in a clear contribution of the SIX2-expressing cells to nephron epithelia, including the glomeruli and presumptive proximal and distal tubules (Fig. 3P). However, induction at day 18 resulted in the identification of a stromal SIX2-derived population but no evidence of ongoing nephrogenesis (Fig. 3P; Howden et al. 2019). Indeed, it is possible that there are distinct SIX2-expressing populations arising at this time that may represent off-target cell types, such a muscle progenitors. This lack of evidence of ongoing nephrogenesis within organoids agrees with the observed morphology that suggests the synchronous formation of tubular structures which subsequently elongate and pattern (Phipson et al. 2019). It also agrees with what would be anticipated in the absence of ureteric tips with a surrounding nephrogenic zone. As such, this is one of the most critical deficits of current organoid protocols. The implications of this become the most stark when one considers the prospects for renal replacement. A number of groups have shown evidence that a transplanted organoid can draw in a host vasculature with evidence of substantive glomerular and tubular maturation (Sharmin et al. 2016; Bantounas et al. 2018; Tanigawa et al. 2018; van den Berg et al. 2018). However, if there is no prospect of ongoing nephrogenesis, all current approaches fall short with respect to tissue mass and will not generate new nephrons after transplantation. When plating $5 \times 10^{5}$ starting cells, we can generate organoids containing $\sim 100$ nephrons (Takasato et al. 2015). This represents a functional shortfall of four orders of magnitude with respect to average nephron number in a human kidney $(\sim 1,000,000 /$ kidney) (Hughson et al. 2003). While this level of endowment is likely sufficient for toxicity screening or disease modeling, it would not represent a tissue capable of renal replacement.

\section{Organoids lack of a dichotomously branching collecting duct}

Recent analysis in the human fetal kidney would suggest that the collecting duct tips should be marked by RET expression (Lindstrom et al. 2018c; Menon et al. 2018; Hochane et al. 2019) as might be predicted from mice (Costantini and Kopan 2010), although single-cell data sets have not definitively described WNT9B expression. Unlike the developing human kidney, a kidney organoid does not arise via the ingrowth of a dichotomously branching ureteric tree comprising $\mathrm{RET}^{+}$ureteric tips (Fig. 5). Indeed, most organoid protocols do not have any evidence for a ureteric epithelium. Takasato et al. (2015) noted the presence of a GATA $3{ }^{+} \mathrm{CDH}^{+}$epithelium, described as collecting duct, that is forming a contiguous network to which the nephrons are attached (Fig. 6A-D). However, global organoid profiling did not detect WNT9B or RET expression. It is possible that this GATA $^{+}$epithelium is actually a connecting segment, a term used to describe the region of the nephron connecting it to the collecting duct epithelium (Little et al. 2007). Lindstrom et al. (2018d) show evidence for the presence for GATA3 protein within the human distal nephron/connecting segment. Mouse lineage tracing clearly shows that the connecting segment is derived from nephron progenitors (Georgas et al. 2009). Curiously, the recent lineage tracing in kidney organoids revealed no Cherry expression (a readout of SIX2 lineage) within this presumptive ureteric epithelium (Fig. 6E), consistent with a distinct origin for this epithelium compared with the rest of the nephron epithelia (Howden et al. 2019). This either supports the identity of this epithelium as ureteric epithelium or suggests that, unlike in the mouse /Georgas et al. 2009|, the connecting segment in human does not arise from the SIX $2^{+}$nephron progenitors.

Our own analysis of the connecting segment in mice, at the level of both gene expression (Fig. 6F) and immunofluorescence (Fig. 6G), also argues that Gata3 protein is present in both connecting segment and ureteric epithelium (Combes et al. 2019b). Indeed, this is also the case for other markers frequently used to identify ureteric epithelium/collecting duct, including Hoxb7, Krt8, Krt18, and Aqp2 (Fig. 6F). As such, these markers can no longer be used to definitively identify ureteric epithelium/collecting duct. This has substantial implications for a number of more recent studies describing the generation of ureteric epithelium/collecting duct from pluripotent stem cells (Xia et al. 2013; Mae et al. 2018; Hariharan et al. 2019).

\section{Relative maturation of kidney organoids}

Alongside the absence of ongoing nephrogenesis, current kidney organoid protocols show little evidence of functional maturation (Fig. 5). As is the case in the mouse or 


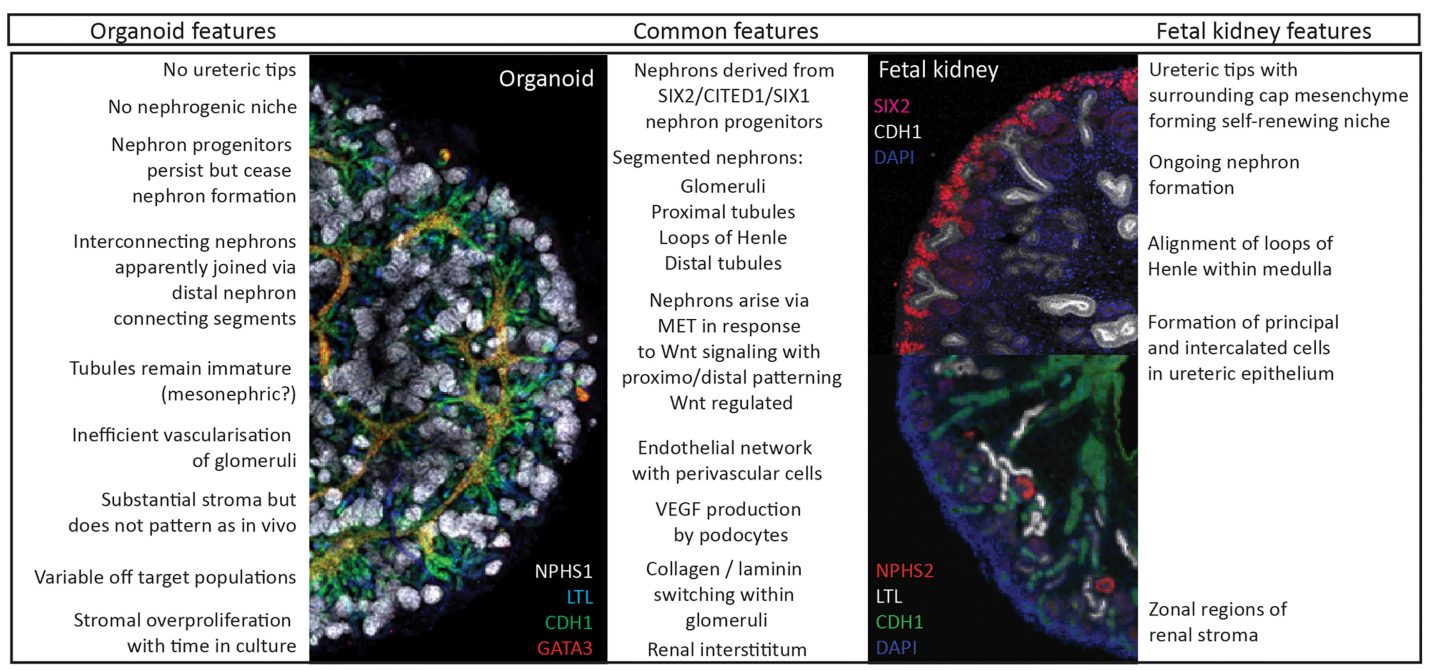

Figure 5. Comparison between fetal kidney and kidney organoids. This diagram highlights the developmental features in common, restricted to normal fetal kidney development (fetal kidney features) or present only in kidney organoids (organoid features).

human fetal kidney, the early nephrons are functionally immature. While the proximal tubules of kidney organoids show expression of CUBULIN and MEGALIN and do show some capacity to endocytose albumin in vitro, they only express low levels of the requisite cationic and anionic solute channels, amino acid transporters and glucose transporters required for postnatal function (Takasato et al. 2015). There have been claims that the proximal tubular segments in kidney organoids are appropriately sensitive to cisplatin and can induce expression of HAVCR1/KIM1 (Freedman et al. 2015; Morizane et al. 2015). Our own analysis does not show evidence of up-regulation of this gene in response to cisplatin (Y-C Soo, $S$ Howden, M Little, unpubl.), which may result from the relative immaturity of the proximal tubular epithelium. Indeed, there is no evidence of substantive SLC22A2/OCT2 expression in organoids (Takasato et al. 2015; Wu et al. 2018; Combes et al. 2019b) that would be required for selective cisplatin uptake. In addition, many of the toxins to which the proximal tubule is sensitive would enter the cell from the urinary filtrate through solute channels displayed on the apical surface of the proximal tubular cells. As no filtrate is forming, this would not occur in an organoid to any extent.

To date, the protocols described for generating kidney organoids have a relatively finite lifespan, with most showing nephron loss, fibrosis, or increasing evidence of off target populations after $\sim 30 \mathrm{~d}$ of in vitro culture. Indeed, with time in culture the center of organoids show deposition of extracellular matrix and a decline in endothelial populations (Takasato et al. 2015). Several approaches to generating kidney organoids in suspension show clear evidence of cyst formation and fibrotic expansion with time (Przepiorski et al. 2018; Kumar et al. 2019). This suggests that while we have managed to replicate early patterning events, we have not created an environment suitable for tubular proliferation and continued development. This is not surprising given the late func- tional maturation of specific nephron segments in the mouse. Nor is it surprising given the absence of a functional vascular supply. Endothelial networks are evident in several protocols (Takasato et al. 2015; Wu et al. 2018; Combes et al. 2019b); however, formation of glomerular capillaries is rare (Fig. 5) and endothelial gene signatures decline with culture time. The application of sheer stress via organoid culture (Morizane protocol) within an addressable PDMS chamber has been shown to sustain and support endothelial populations and their vascularization of organoids in vitro (Homan et al. 2019). However, it is the provision of a host vasculature that definitely appears to improve tubular morphology, with evidence of the formation of intercalated cells within the distal epithelial segments of our own organoid protocol within 2 wk of renal subcapsular transplantation (van den Berg et al. 2018). In contrast, an organoid left to grow in vitro for the same period of time shows no evidence of maturation (van den Berg et al. 2018). The capacity to mimic such a vascular supply in vitro is challenging, but is likely to be required if we wish to mature the proximal tubule to the stage of having mature transporter activity and barrier function. Without these traits, kidney organoids will struggle to prove useful for toxicology screening or modeling of certain tubulopathies.

There has been some suggestion that kidney organoids may also prove useful in screening for treatment or improving our understanding of postnatal renal pathologies, including interstitial fibrosis, diabetic nephropathy, or glomerulosclerosis. Here again, current kidney organoid models fall short of what would be required to accurately model such conditions. For example, diabetic nephropathy arises in response to continuous high levels of circulating glucose. While is it clear that some individuals show higher risk of nephropathic complications than others, without the presence of a circulation, fenestrated glomerular capillaries or a glomerular basement membrane, it is not clear whether this can be modeled in vitro. In 

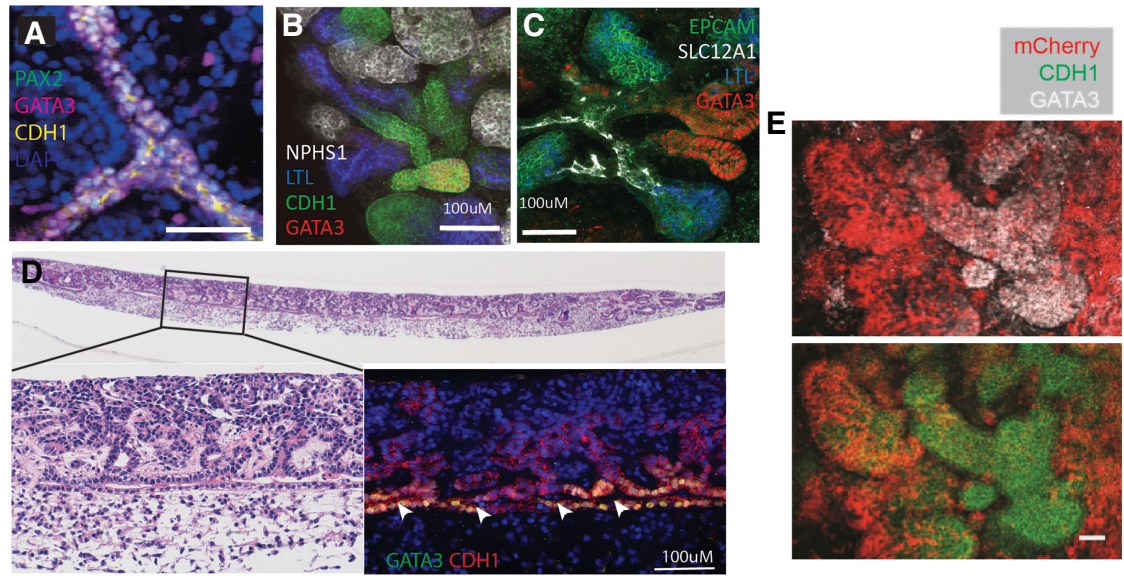

$\mathbf{F}$
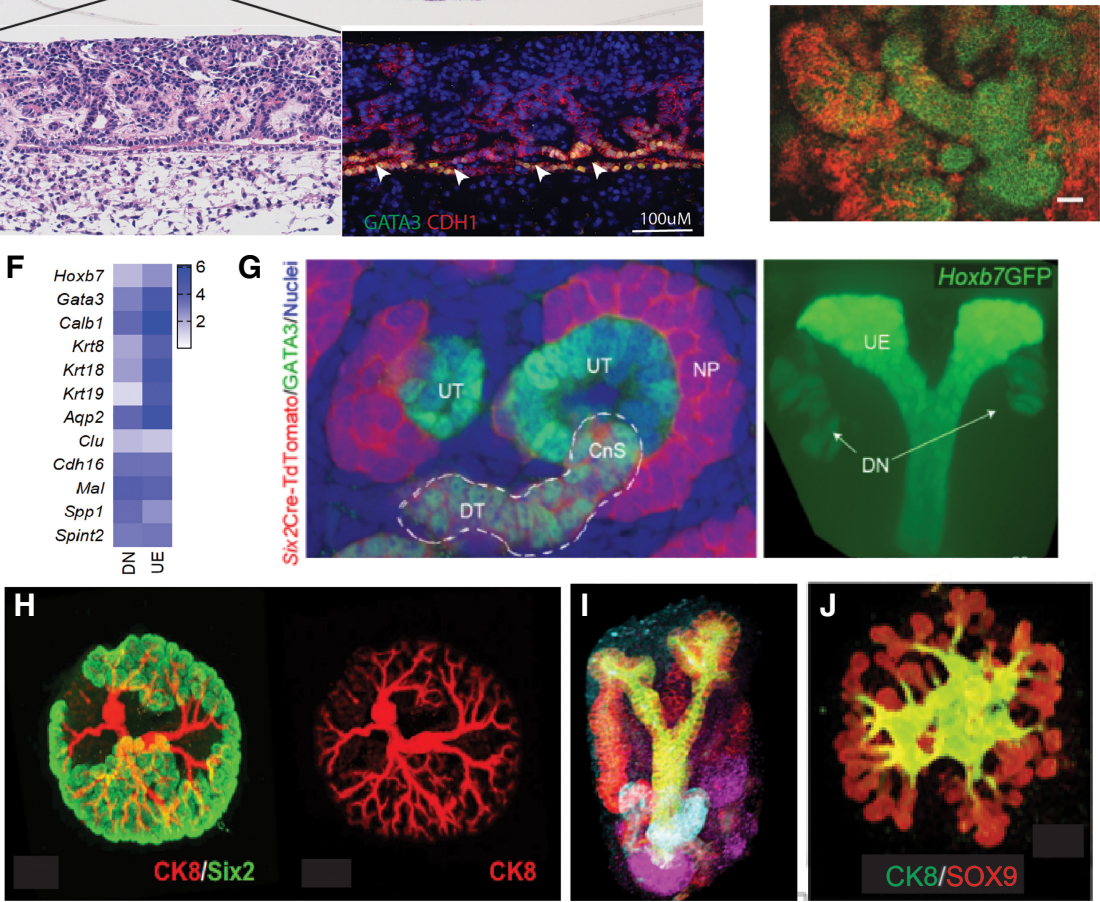

Figure 6. The challenge of a higher order kidney from induced pluripotent stem cells. (A) Immunofluorescence of putative collecting duct within human kidney organoid. PAX2 (green), GATA3 (purple), CDH1 (yellow). $(B)$ Evidence for an intervening nephron segment $\left(\mathrm{CDH}^{+}\right)$between the proximal nephron (LTL; blue) and the putative collecting duct $\left(\mathrm{CDH}^{+} \mathrm{GATA}^{+}\right)$. (C) Evidence for an intervening nephron segment $\left(\mathrm{CDH}^{+}\right)$between the thick ascending limb/distal straight tubule (SLC12A1; white) and the putative collecting duct (GATA3, red). (D) Sectioned kidney organoids showing evidence for a contiguous $\mathrm{GATA}^{+} \mathrm{CDH}^{+}{ }^{+}$epithelium connecting all nephrons within the kidney organoid. Reprinted from Higgins et al. (2018). (E) Lineage tracing shows contribution of SIX2expressing cells to nephron segments other than the distal GATA3-expressing region. From Howden et al. (2019). (F) Comparison of expression between E18.5 mouse kidney distal nephron and collecting duct shows coexpression of many genes assumed to be collecting duct specific, including Hoxb7, Gata3, Calb1, Krt8, Krt18, and Aqp2. Reprinted from Combes et al. (2019a). (G) Evidence in mouse for expression of Gata3 and Hoxb7 within distal nephron (DN), including distal tubule (DT) and connecting segment $(\mathrm{CnS})$, as well as ureteric epithelium (UE)/ureteric tip (UT). Lineage tracing using the SIX2Cre-TdTomato shows a nephron progenitor $(\mathrm{NP})$ origin for the DT and $\mathrm{CnS}$ but not the UT. Reprinted from Combes et al. (2019a) with permission from Elsevier. $(H, I)$ Immunofluorescence of a murine higher order kidney organoid generated after combining mouse ESC-derived nephron progenitor and collecting duct progenitors with Foxd1-sorted mouse stroma. $(H)$ Evidence for a branching collecting duct tree (CK8; red) and a peripheral nephron progenitor (Six2) population. (I) Evidence for the initiation of nephrons which connect to the collecting duct tree. Reprinted from Taguchi and Nishinakamura (2017). (J) A branching presumptive collecting duct structure generated from human IPSC differentiated using directed differentiation to ureteric epithelium. Reprinted from Taguchi and Nishinakamura (2017).

addition, almost all tissue culture media are high in glucose, making the control situation abnormal with respect to glucose. Indeed, it is possible that this abnormal metabolic environment itself may hinder the capacity for a kidney organoid to mature normally. Hence, it is likely that there will need to be many more modifications to our differentiation protocols and culture formats before solutions to such challenges are found.

\section{Other points of divergence between developing organ and organoid}

The absence of ongoing nephrogenesis within organoids limits both the nephron number and potentially other aspects of morphogenesis. Given the clinical relevance of renal hypoplasia (small kidneys), let alone frank dysplasia, all such inaccuracies have the potential to be major problems to the utility of organoids. Indeed, it is understanding the points of divergence that will focus efforts on improving the differentiation protocols as well as refining organoid applications (Fig. 5).

The stroma of the developing kidney, while poorly understood, is clearly required to refine the process of organ morphogenesis. Signals from the stroma are critical in the elongation of the nephrons (Yu et al. 2009) and support of the cap mesenchyme (Das et al. 2013). Kidney organoids contain a complex set of stromal populations; however, these are not arranged in the same way as the developing kidney. Indeed, while there is evidence for occasional FOXD $1^{+}$stromal cells, these are not prevalent or patterned into a cortical stromal zone. It is possible that this results in part from the fact that not all stromal elements of the developing kidney arise within the metanephric mesenchyme. For example, the medullary Tbx $18^{+}$stroma of the mouse likely migrates into the kidney with the ureteric bud (Bohnenpoll et al. 2013). Hence, some stromal compartments may simply not be present 
in kidney organoids while others may be off target populations.

While nephrons form and undergo patterning and segmentation, the detailed morphology of organoid nephrons have not been comprehensively studied. In our own protocol, we have evidence that kidney organoids contain early nephrons that are connecting to each other. While this process of nephron-to-nephron connections is only rarely referred to in descriptions of mouse metanephric development (Zhai et al. 2006), this nephron-to-nephron connectivity in organoids may represent the process of arcading known to occur in the human fetal kidney after collecting duct branching ends in early Trimester 2 (Little 2015). Indeed, a fundamental difference between mouse and human kidney development is the prolonged period of nephron formation without ureteric branching seen in the human fetal kidney ( 16-20 wk) (Little 2015). While arcading may occur in the first week of neonatal life of the mouse, the period where nephrogenesis ceases (Rumballe et al. 2011), this is not well appreciated. A second alternative is that the nephrons arising in most organoid protocols are not metanephric but are mesonephric tubules. There is strong transcriptional congruence between mesonephric and metanephric tubules in the mouse (Georgas et al. 2011). As the human mesonephros arises around week 4 after conception, there is no transcriptional data available in human. However, if it is assumed that the pace at which a human pluripotent stem cell can pattern to a specific endpoint is linked to the speed at which the tissue would arise in vivo, a kidney organoid arising at day 25 may be mesonephric, or even pronephric. This does not explain why a mesonephric, or indeed, a pronephric tubule, would be likely to connect to one other as this is not an anatomical feature of the mesonephros in mouse or human. The formation of interconnecting mesonephric tubules is, however, a feature of mesonephros formation and regeneration in the fish (Gallegos et al. 2019). Hence, if the same patterning processes applies, this unusual fusion of adjacent nephrons may simply represent an aberrant feature of in vitro culture unique to kidney organoids.

\section{Changing culture formats to improve kidney organoids}

Clearly, kidney organoids remain imperfect models of the developing human organ. Major challenges remain around structure, functional maturation, and scale, all of which will impact on the feasibility and accuracy of applications including disease modeling, toxicological screening, and regenerative approaches. Despite this, a number of studies have shown a capacity to recapitulate genetic forms of kidney disease in vitro, including nephronophthisis and congenital nephrotic syndrome, using patient-derived iPSC (Forbes et al. 2018; Hale et al. 2018; Tanigawa et al. 2018). What is possible outside of the embryo is to modify culture format to optimize such models for one or other application, even when this does not necessarily involve creating a perfect model of the developing organ. A variety of studies have now claimed improvements in scale up or relative maturation, including the use of dis- tinct culture formats and changes in culture materials (Table 2; Cruz et al. 2017; Czerniecki et al. 2018; Przepiorski et al. 2018; Garreta et al. 2019; Gupta et al. 2019; Kumar et al. 2019). In addition, protocols for the generation of specific renal cell subtypes, such as podocyte or collecting duct epithelium, are being reported (Musah et al. 2017; Taguchi and Nishinakamura 2017; Hale et al. 2018; Yoshimura et al. 2019|. Finally, a variety of approaches have now been proposed to improve vascularization in vitro (Homan et al. 2019) or provide vascular flow in vivo (Sharmin et al. 2016; Bantounas et al. 2018; van den Berg et al. 2018; Garreta et al. 2019; Gupta et al. 2019|. In most instances, these involve modifications of prior differentiation protocols (Table 2; Taguchi et al. 2014; Freedman et al. 2015; Morizane et al. 2015; Takasato et al. 2015).

One of the earliest conformational changes proposed was to move from adherent or micromass culture to suspension culture. Cruz et al. (2017) reported that this allowed for the presentation of epithelial cysts within cultures derived from stem cell lines into which autosomal dominant polycystic kidney disease gene mutations (homozygous PKD1 mutations) were engineered (Table 2). Two more recent adaptations of the Takasato protocol have cultured early EBs, or micro-organoids generated from IM in suspension cultures, achieving a significant scale up in terms of final cell number (Table 2; Przepiorski et al. 2018; Kumar et al. 2019). However, both of these studies reported inappropriate stromal expansion and epithelial cyst formation even within organoids generated from control cell lines, either suggesting that these cultures failed to progress without pathological change or that they did not pattern as accurately when cultured in this format.

As described above, maturation of kidney organoids from early patterning and segmenting nephrons (human trimester 1) to mature functional epithelium has been a major challenge. While endothelial cells appear to be present in a number of protocols, these do not appear to persist with prolonged culture. The use of PDMS microchambers within which organoids are cultured under appropriate flow has been shown to increase the viability of the component endothelial cell population and their invasion of the forming glomeruli (Homan et al. 2019). iPSC-derived podocytes have also been subjected to flow within a chip and in co-culture with endothelial cells, reportedly leading to an increase in podocyte gene expression to that equivalent to an immortalized human podocyte cell line (Musah et al. 2017). While it is clear that increased mechanical stress on mesenchymal stem cell differentiation can shift differentiation from fat to bone, it is also likely that Transwell culture, while apparently conducive to kidney organoid patterning, may not be the ideal environment for kidney culture. Hence, it is quite feasible that optimization of the biomaterials upon which an organoid is grown may influence the outcome. A recent study claims that the initial culture of undifferentiated iPSC on a hydrogel environment improves the maturation of the resulting organoids, while culture of the end product on a compliant hydrogel tuned to the 
stiffness of the chick chorioallantoic membrane is said to promote the relative amount of WT1- and LTL-positive structures within kidney organoids (Garreta et al. 2019). Given the apparent technical variation between lines and between experiments with the same line, which has now been documented at the level of global and single cell RNAseq (Phipson et al. 2019), such claims may need more careful examination. Indeed, a transcriptional comparison of $1-\mathrm{kPA}$ and $60-\mathrm{kPa}$ hydrogels with transwell filters was not made. Nevertheless, investigations into variations in plating and culture conditions will likely continue as we try to improve functional readouts for specific organoid uses.

Another incentive for changes in the format of culture has been the desire for high-content screening, either to dissect or improve differentiation conditions or to screen for drug toxicity or efficacy. Czerniecki et al. (2018) used a liquid handling robot to plate their initial cultures into 96-well formats, thereby automating the process of initiating differentiation to kidney. In their proof of principle, they used this approach to optimize the concentration of Wnt agonist in early patterning. This revealed considerable variability between experiments. We have recently used extrusion bioprinting to automate the process of generating a micromass culture at the stage of IM, facilitating the generation of large numbers of identical kidney organoids with a very low coefficient of variation as is required for screening (Higgins et al. 2018). Such approaches have the potential of modification for high-content 3D screening when coupled with a rapid readout such as can be conferred via the use of fluorescent reporter hPSC lines (Boreström et al. 2018; Howden et al. 2018; Vanslambrouck et al. 2019).

Perhaps the most important improvement required is the capacity for what is essentially a very early model of the kidney to "grow up." While formation of a urinary filtrate commences as soon as an immature glomerulus forms a capillary network, the tubular maturation required for appropriate balance of water, regulation of $\mathrm{pH}$, and control of loss of proteins, glucose, $\mathrm{Na}$, phosphorus, $\mathrm{Ca}$, and $\mathrm{K}$ is not present until after birth. The profiling of kidney organoids performed to date confirms the immaturity of the tubular epithelium (Wu et al. 2018; Combes et al. 2019b). What is evident is that the provision of an ex vivo blood supply does improve tubular ultrastructure. This has been achieved via transplantation either under the renal capsule or subcutaneously in immunocompromised mice or culture of organoids on the chick chorioallantoic membrane (Bantounas et al. 2018; van den Berg et al. 2018; Garreta et al. 2019). In both examples, a nascent host-derived vasculature grows into the grafted organoid with TEM evidence for the presence of glomerular capillaries. In one study, based on the use of fluorescent reporter lines, multiphoton live imaging showed murine blood-flow through organoid glomeruli with evidence of human endothelial cell contribution to the neovasculature (van den Berg et al. 2018). Recent data single-cell profiling such organoids after transplantation claim to show a reduction in off-target populations after transplantation (Subramanian et al. 2019). Given the capacity for organoid to spontaneously vascularise, likely as a result of VEGF expression by the forming podocytes in the graft, this raises the prospect of generating hPSC-derived replacement tissue for the provision of renal replacement. It should be remembered that even the largest organoids described to date have 100 nephrons (Takasato et al. 2015). There would also have to be a capacity for urine to exit the graft. Finally, the entire process would require appropriate quality control processes to ensure off-target differentiation did not result in teratoma formation. From a developmental perspective, however, the apparent capacity for vascular flow to improve histology is an interesting phenomenon and one, if more completely understood, that may assist us in engineering more mature structures for in vitro applications such as drug screening.

\section{Building a higher-order kidney}

While there has been intense focus on adapting currently described kidney organoid protocols for applications such as disease modeling, there has been arguably less focus on a careful analysis of developmental morphological accuracy and how this can be improved. While a replacement tissue may be the most ambitious target, remaining cognoscente of where we have and have not accurately modeled the developing kidney remains important. The key deficits of current organoid models lie in the absence of a nephrogenic zone (Fig. 5). Indeed, in their seminal study, Taguchi et al. (2014) argued that it should not be possible to simultaneously generate both the ureteric bud and the nephrogenic mesenchyme. This was based on the fact that during normal mouse development the Wolffian duct arose early and in a more anterior region of the intermediate mesoderm before elongating to give rise to the ureteric bud, whereas the metanephric mesenchyme arose later in a more posterior position (Taguchi et al. 2014). In line with their proposal that a distinct protocol would be required for the formation of a true collecting duct, this group have recently developed a distinct collecting duct differentiation protocol (Taguchi and Nishinakamura 2017). This is again based on mouse development and involves patterning to a more anterior intermediate mesodermal population then the isolation of a $\mathrm{CKIT}^{+} \mathrm{CXCR} 4^{+}$subpopulation that can be induced to undergo epithelial branching in vitro in response to GDNF. In order to create a more accurate model of the developing kidney, they combined their mouse ESC-derived nephron progenitors with mouse ESC-derived collecting duct progenitors and mouse fetal kidney stroma. The resulting "higher-order" organoids showed beautiful collecting duct tree branching with evidence of forming and attaching nephrons (Fig. $6 \mathrm{HIJ})$. Immunostaining for Six2 also suggested the maintenance of a nephron progenitor population (Fig. $6 \mathrm{H}$ ). This was a remarkable achievement and a very promising advance. However, it was not evident whether nephrogenesis was continuing in such structures or whether once again such models had a finite nephron-forming capacity. Importantly, this approach was not successful in the human pluripotent stem cell context. This is likely to be 
due to the lack of an appropriate human stromal population as in the mouse system this appears to be required to support the other two populations. Indeed, it has proven very difficult in the field to define conditions within which it is possible to maintain mouse nephron progenitor cells in vitro. This group (Tanigawa et al. 2016) and others (Brown et al. 2015; Li et al. 2016) have developed media for this purpose. While the culture conditions used by this group to generate nephron progenitors from pluripotent stem cells does not utilize this maintenance media for their support, it still requires an active induction to get nephrons to form. Factors from a supporting stroma may assist.

What human stroma would be required to create a human "higher-order" kidney? While the Foxd1 $1^{+}$cortical stroma would normally surround the nephron progenitors of the nephrogenic zone in mouse, in human FOXD1 and even MEIS1 protein is seen in the nephron progenitors (Lindstrom et al. 2018b). This is also not the stromal population present along the branching collecting duct. Indeed, there appear to be a number of distinct stromal zones within the developing mouse kidney, as evidenced by distinct patterns of gene expression both using in situ hybridization (GUDMAP) and at the single-cell transcriptional level (Magella et al. 2018; Combes et al. 2019b). Available single-cell profiling of human fetal kidney also identifies many distinct stromal subpopulations. Similarly, single-cell analysis of our own organoid protocol identifies a number of distinct stromal populations (Combes et al. 2019b). Hence, it seems that in some kidney organoid protocols a variety of potentially required stromal cell types may already exist, although whether these are sufficient for driving morphogenesis or off target is not clear.

Another possibility is that the two human pluripotent stem cell-derived populations combined in Taguchi and Nishinakamura (2017) were each inappropriately specified. While differentiation of a human branching epithelium positive for CK8 and SOX9 was evident (Fig. 6J), again these markers are not definitive of ureteric epithelium. No single-cell profiling was performed on either the putative collecting duct or nephron progenitor cultures generated by Taguchi and Nishinakamura (2017). Indeed, the QPCR profiling performed included genes previously noted to not be definitive of this population, including $P A X 2$, $P A X 8, L H X 1$, and GATA3. Conversely, no QPCR was performed for stroma subpopulations. Identifying the right combinations of all required patterning populations may prove to be very complex. However, without a capacity to continue to generate nephrons, the capacity to generate renal replacement tissue may be limited.

\section{Conclusions}

In summary, the capacity to direct differentiation of pluripotent stem cells through mesodermal patterning to early kidney is a remarkable technical leap. The simultaneous formation of a complex multicellular model of the developing kidney is testament to the power of em- bryogenic self-organization and illustrates the capacity for distinct cell types arising within kidney organoids to communicate with each other to generate a complex structure. However, as we have discussed here, at present, human pluripotent stem cell-derived kidney organoids represent an inaccurate model of the developing human kidney. While key component cells and structures are apparent, with evidence of transcriptional congruence with the developing organ in man, the accuracy of the differentiation varies, cellular representation is unbalanced, and distinct populations are not present. In addition, off target populations appear to arise with significant variation between individual differentiations. Overall, this suggests that a tightening of the patterning is required for accurate organoid formation. While changes in culture format and differentiation optimizations are likely to improve the cellular complexity, repertoire, and maturation of individual components, it may prove impossible to mature all organoid cell types in vitro and transplantation may be essential to provide appropriate urinary filtrate formation and hence flow.

\section{Acknowledgments}

We thank Jessica Vanslambrouck, Sara Howden, Kynan Lawlor, Lorna Hale, Julie Moreau, Sean Wilson, Ker Sin Tan, Lakshi Starks, Shahnaz Khan, Belinda Phipson, Luke Zappia from the Murdoch Childrens Research Institute, Tomoyo Miyashi and Ryuji Morizane from Brigham and Women's Hospital, Kimberley Homan, Navin Gupta and Jennifer Lewis from Harvard University and Benjamin Freedman and Nelly Cruz from University of Washington for the provision of images. M.H.L. is a Senior Principal Research Fellow of the National Health and Medical Research Council of Australia (GNT1136085). MHL and A.N.C. receive funding from the NHMRC (GNT1156567) in the area of kidney development. A.N.C. receives funding from the Australian Research Council (DP190101037). M.H.L. receives funding from the National Health and Medical Research Council (GNT1100970, GNT1098654) and the National Institutes of Health (DK107344-02) for research into kidney organoids.

\section{References}

Adam M, Potter AS, Potter SS. 2017. Psychrophilic proteases dramatically reduce single-cell RNA-seq artifacts: a molecular atlas of kidney development. Development 144: 3625-3632. doi:10.1242/dev.151142

Bagherie-Lachidan M, Reginensi A, Pan Q, Zaveri HP, Scott DA, Blencowe BJ, Helmbacher F, McNeill H. 2015. Stromal Fat4 acts non-autonomously with $D$ chs $1 / 2$ to restrict the nephron progenitor pool. Development 142: 2564-2573. doi:10.1242/ dev. 122648

Bantounas I, Ranjzad P, Tengku F, Silajdžić E, Forster D, Asselin MC, Lewis P, Lennon R, Plagge A, Wang Q, et al. 2018. Generation of functioning nephrons by implanting human pluripotent stem cell-derived kidney progenitors. Stem Cell Reports 10: 766-779. doi:10.1016/j.stemcr.2018.01.008

Barak H, Huh SH, Chen S, Jeanpierre C, Martinovic J, Parisot M, Bole-Feysot C, Nitschké P, Salomon R, Antignac C, et al. 2012. FGF9 and FGF20 maintain the stemness of nephron progenitors in mice and man. Dev Cell 22: 1191-1207. doi:10 .1016/j.devcel.2012.04.018 
Barker N, Rookmaaker MB, Kujala P, Ng A, Leushacke M, Snippert $\mathrm{H}$, van de Wetering $\mathrm{M}$, Tan S, Van Es JH, Huch $M$, et al. 2012. Lgr $^{\text {tve }}$ stem/progenitor cells contribute to nephron formation during kidney development. Cell Rep 2: 540-552. doi:10.1016/j.celrep.2012.08.018

Bohnenpoll T, Bettenhausen E, Weiss AC, Foik AB, Trowe MO, Blank P, Airik R, Kispert A. 2013. Tbx18 expression demarcates multipotent precursor populations in the developing urogenital system but is exclusively required within the ureteric mesenchymal lineage to suppress a renal stromal fate. Dev Biol 380: 25-36. doi:10.1016/j.ydbio.2013.04.036

Boreström C, Jonebring A, Guo J, Palmgren H, Cederblad L, Forslöw A, Svensson A, Söderberg M, Reznichenko A, Nyström J, et al. 2018. A CRISP(e)R view on kidney organoids allows generation of an induced pluripotent stem cell-derived kidney model for drug discovery. Kidney Int 94: 1099-1110. doi:10 $.1016 /$ j.kint.2018.05.003

Boyle S, Misfeldt A, Chandler KJ, Deal KK, Southard-Smith EM, Mortlock DP, Baldwin HS, de Caestecker M. 2008. Fate mapping using Cited1-CreERT2 mice demonstrates that the cap mesenchyme contains self-renewing progenitor cells and gives rise exclusively to nephronic epithelia. Dev Biol 313: 234-245. doi:10.1016/j.ydbio.2007.10.014

Brown AC, Muthukrishnan SD, Oxburgh L. 2015. A synthetic niche for nephron progenitor cells. Dev Cell 34: 229-241. doi:10.1016/j.devcel.2015.06.021

Camp JG, Badsha F, Florio M, Kanton S, Gerber T, Wilsch-Brauninger M, Lewitus E, Sykes A, Hevers W, Lancaster M, et al. 2015. Human cerebral organoids recapitulate gene expression programs of fetal neocortex development. Proc Natl Acad Sci 112: $15672-15677$.

Carroll TJ, Park JS, Hayashi S, Majumdar A, McMahon AP. 2005. Wnt9b plays a central role in the regulation of mesenchymal to epithelial transitions underlying organogenesis of the mammalian urogenital system. Dev Cell 9: 283-292. doi:10 .1016/j.devcel.2005.05.016

Cebrián C, Borodo K, Charles N, Herzlinger DA. 2004. Morphometric index of the developing murine kidney. Dev Dyn 231: 601-608. doi:10.1002/dvdy.20143

Cheng HT, Miner JH, Lin M, Tansey MG, Roth K, Kopan R. 2003. $\gamma$-secretase activity is dispensable for mesenchyme-to-epithelium transition but required for podocyte and proximal tubule formation in developing mouse kidney. Development 130: 5031-5042. doi:10.1242/dev.00697

Cheng HT, Kim M, Valerius MT, Surendran K, Schuster-Gossler K, Gossler A, McMahon AP, Kopan R. 2007. Notch2, but not Notch1, is required for proximal fate acquisition in the mammalian nephron. Development 134: 801-811. doi:10.1242/dev .02773

Chi X, Michos O, Shakya R, Riccio P, Enomoto H, Licht JD, Asai N, Takahashi M, Ohgami N, Kato M, et al. 2009. Ret-dependent cell rearrangements in the Wolffian duct epithelium initiate ureteric bud morphogenesis. Dev Cell 17: 199-209. doi:10.1016/j.devcel.2009.07.013

Chung E, Deacon P, Marable S, Shin J, Park JS. 2016. Notch signaling promotes nephrogenesis by downregulating Six2. Development 143: 3907-3913. doi:10.1242/dev.143503

Chung E, Deacon P, Park JS. 2017. Notch is required for the formation of all nephron segments and primes nephron progenitors for differentiation. Development 144: 4530-4539. doi:10 $.1242 /$ dev.156661

Combes AN, Short KM, Lefevre J, Hamilton NA, Little MH, Smyth IM. 2014. An integrated pipeline for the multidimensional analysis of branching morphogenesis. Nat Protoc 9: 2859-2879. doi:10.1038/nprot.2014.193
Combes AN, Lefevre JG, Wilson S, Hamilton NA, Little MH. 2016. Cap mesenchyme cell swarming during kidney development is influenced by attraction, repulsion, and adhesion to the ureteric tip. Dev Biol 418: 297-306. doi:10.1016/j.ydbio .2016 .06 .028

Combes AN, Phipson B, Lawlor KT, Dorison A, Patrick R, Zappia L, Harvey RP, Oshlack A, Little MH. 2019a. Single cell analysis of the developing mouse kidney provides deeper insight into marker gene expression and ligand-receptor crosstalk. Development 143: 13.

Combes AN, Zappia L, Er PX, Oshlack A, Little MH. 2019b. Single-cell analysis reveals congruence between kidney organoids and human fetal kidney. Genome Med 11: 3. doi:10 .1186/s13073-019-0615-0

Cortez AR, Poling HM, Brown NE, Singh A, Mahe MM, Helmrath MA. 2018. Transplantation of human intestinal organoids into the mouse mesentery: A more physiologic and anatomic engraftment site. Surgery 164: 643-650. doi:10.1016/j.surg .2018 .04 .048

Costantini F, Kopan R. 2010. Patterning a complex organ: branching morphogenesis and nephron segmentation in kidney development. Dev Cell 18: 698-712. doi:10.1016/j.devcel.2010 .04 .008

Cruz NM, Song X, Czerniecki SM, Gulieva RE, Churchill AJ, Kim YK, Winston K, Tran LM, Diaz MA, Fu H, et al. 2017. Organoid cystogenesis reveals a critical role of microenvironment in human polycystic kidney disease. Nat Mater 16: 11121119. doi: $10.1038 /$ nmat 4994

Czerniecki SM, Cruz NM, Harder JL, Menon R, Annis J, Otto EA, Gulieva RE, Islas LV, Kim YK, Tran LM, et al. 2018. Highthroughput screening enhances kidney organoid differentiation from human pluripotent stem cells and enables automated multidimensional phenotyping. Cell Stem Cell 22: 929940.e4. doi:10.1016/j.stem.2018.04.022

Daniel E, Azizoglu DB, Ryan AR, Walji TA, Chaney CP, Sutton GI, Carroll TJ, Marciano DK, Cleaver O. 2018. Spatiotemporal heterogeneity and patterning of developing renal blood vessels. Angiogenesis 21: 617-634. doi:10.1007/s10456-0189612-y

Das A, Tanigawa S, Karner CM, Xin M, Lum L, Chen C, Olson EN, Perantoni AO, Carroll TJ. 2013. Stromal-epithelial crosstalk regulates kidney progenitor cell differentiation. Nat Cell Biol 15: 1035-1044. doi:10.1038/ncb2828

Daviaud N, Friedel RH, Zou H. 2018. Vascularization and engraftment of transplanted human cerebral organoids in mouse cortex. eNeuro 5: ENEURO.0219-18.2018. doi:10.1523/ENEURO $.0219-18.2018$

Doetschman TC, Eistetter H, Katz M, Schmidt W, Kemler R. 1985. The in vitro development of blastocyst-derived embryonic stem cell lines: formation of visceral yolk sac, blood islands and myocardium. J Embryol Exp Morphol 87: 27-45.

Dong L, Pietsch S, Tan Z, Perner B, Sierig R, Kruspe D, Groth M, Witzgall R, Gröne HJ, Platzer M, et al. 2015. Integration of cistromic and transcriptomic analyses identifies Nphs2, Mafb, and Magi2 as Wilms' Tumor 1 target genes in podocyte differentiation and maintenance. J Am Soc Nephrol 26: 2118-2128. doi:10.1681/ASN.2014080819

Eiraku M, Watanabe K, Matsuo-Takasaki M, Kawada M, Yonemura S, Matsumura M, Wataya T, Nishiyama A, Muguruma K, Sasai Y. 2008. Self-organized formation of polarized cortical tissues from ESCs and its active manipulation by extrinsic signals. Cell Stem Cell 3: 519-532. doi:10.1016/j.stem.2008.09 .002

Eiraku M, Takata N, Ishibashi H, Kawada M, Sakakura E, Okuda S, Sekiguchi K, Adachi T, Sasai Y. 2011. Self-organizing optic- 
cup morphogenesis in three-dimensional culture. Nature 472: 51-56. doi:10.1038/nature09941

Forbes TA, Howden SE, Lawlor K, Phipson B, Maksimovic J, Hale L, Wilson S, Quinlan C, Ho G, Holman K, et al. 2018. PatientiPSC-derived kidney organoids show functional validation of a ciliopathic renal phenotype and reveal underlying pathogenetic mechanisms. Am J Hum Genet 102: 816-831. doi:10.1016/j .ajhg.2018.03.014

Freedman BS, Brooks CR, Lam AQ, Fu H, Morizane R, Agrawal V, Saad AF, Li MK, Hughes MR, Werff RV, et al. 2015. Modelling kidney disease with CRISPR-mutant kidney organoids derived from human pluripotent epiblast spheroids. Nat Commun 6: 8715 . doi:10.1038/ncomms 9715

Fujimura S, Jiang Q, Kobayashi C, Nishinakamura R. 2010. Notch2 activation in the embryonic kidney depletes nephron progenitors. J Am Soc Nephrol 21: 803-810. doi:10.1681/ASN .2009040353

Gallegos TF, Kamei CM, Rohly M, Drummond IA. 2019. Fibroblast growth factor signaling mediates progenitor cell aggregation and nephron regeneration in the adult zebrafish kidney. Dev Biol 454: 44-51.

Garreta E, Prado P, Tarantino C, Oria R, Fanlo L, Marti E, Zalvidea D, Trepat X, Roca-Cusachs P, Gavalda-Navarro A, et al. 2019. Fine tuning the extracellular environment accelerates the derivation of kidney organoids from human pluripotent stem cells. Nat Mater 18: 397-405. doi:10.1038/s41563-0190287-6

Georgas K, Rumballe B, Valerius MT, Chiu HS, Thiagarajan RD, Lesieur E, Aronow BJ, Brunskill EW, Combes AN, Tang D, et al. 2009. Analysis of early nephron patterning reveals a role for distal RV proliferation in fusion to the ureteric tip via a cap mesenchyme-derived connecting segment. DeV Biol 332: 273-286. doi:10.1016/j.ydbio.2009.05.578

Georgas KM, Chiu HS, Lesieur E, Rumballe BA, Little MH. 2011. Expression of metanephric nephron-patterning genes in differentiating mesonephric tubules. Dev Dyn 240: 1600-1612. doi:10.1002/dvdy.22640

Gupta AK, Coburn JM, Davis-Knowlton J, Kimmerling E, Kaplan DL, Oxburgh L. 2019. Scaffolding kidney organoids on silk. $J$ Tissue Eng Regen Med 13: 812-822.

Hale LJ, Howden SE, Phipson B, Lonsdale A, Er PX, Ghobrial I, Hosawi S, Wilson S, Lawlor KT, Khan S, et al. 2018. 3D organoid-derived human glomeruli for personalised podocyte disease modelling and drug screening. Nat Commun 9: 5167. doi:10.1038/s41467-018-07594-z

Harder JL, Menon R, Otto EA, Zhou J, Eddy S, Wys NL, O'Connor C, Luo J, Nair V, Cebrian C, et al. 2019. Organoid single cell profiling identifies a transcriptional signature of glomerular disease. JCI Insight 4: 122697. doi:10.1172/jci.insight.122697

Hariharan K, Stachelscheid H, Rossbach B, Oh SJ, Mah N, Schmidt-Ott K, Kurtz A, Reinke P. 2019. Parallel generation of easily selectable multiple nephronal cell types from human pluripotent stem cells. Cell Mol Life Sci 76: 179-192. doi:10 .1007/s00018-018-2929-2

Hartman HA, Lai HL, Patterson LT. 2007. Cessation of renal morphogenesis in mice. Dev Biol 310: 379-387. doi:10.1016/j .ydbio.2007.08.021

Heliot C, Desgrange A, Buisson I, Prunskaite-Hyyrylainen R, Shan J, Vainio S, Umbhauer M, Cereghini S. 2013. HNF1B controls proximal-intermediate nephron segment identity in vertebrates by regulating Notch signalling components and Irx1/2. Development 140: 873-885. doi:10.1242/dev.086538

Hendry CE, Vanslambrouck JM, Ineson J, Suhaimi N, Takasato M, Rae F, Little MH. 2013. Direct transcriptional reprogram- ming of adult cells to embryonic nephron progenitors. J Am Soc Nephrol 24: 1424-1434. doi:10.1681/ASN.2012121143

Higgins JW, Chambon A, Bishard K, Hartung A, Arndt D, Brugnano J, Xuan Er P, Lawlor KT, Vanslambrouck JM, Wilson S, et al. 2018. Bioprinted pluripotent stem cell-derived kidney organoids provide opportunities for high content screening. bioRxiv: 505396.

Hirst CE, Ng ES, Azzola L, Voss AK, Thomas T, Stanley EG, Elefanty AG. 2006. Transcriptional profiling of mouse and human ES cells identifies SLAIN1, a novel stem cell gene. DeV Biol 293: 90-103. doi:10.1016/j.ydbio.2006.01.023

Hochane M, van den Berg PR, Fan X, Berenger-Currias N, Adegeest E, Bialecka M, Nieveen M, Menschaart M, Chuva de Sousa Lopes SM, Semrau S. 2019. Single-cell transcriptomics reveals gene expression dynamics of human fetal kidney development. PLoS Biol 17: e3000152. doi:10.1371/journal.pbio .3000152

Homan KA, Gupta N, Kroll KT, Kolesky DB, Skylar-Scott M, Miyoshi T, Mau D, Valerius MT, Ferrante T, Bonventre JV, et al. 2019. Flow-enhanced vascularization and maturation of kidney organoids in vitro. Nat Methods 16: 255-262. doi:10.1038/s41592-019-0325-y

Howden SE, Thomson JA, Little MH. 2018. Simultaneous reprogramming and gene editing of human fibroblasts. Nat Protoc 13: $875-898$. doi:10.1038/nprot.2018.007

Howden SE, Vanslambrouck JM, Wilson SB, Tan KS, Little MH. 2019. Reporter-based fate mapping in human kidney organoids confirms nephron lineage relationships and reveals synchronous nephron formation. EMBO Rep 20: e47483. doi:10 .15252/embr.201847483

Hughson M, Farris AB III, Douglas-Denton R, Hoy WE, Bertram JF. 2003. Glomerular number and size in autopsy kidneys: the relationship to birth weight. Kidney Int 63: 2113-2122. doi:10.1046/j.1523-1755.2003.00018.x

Kann M, Ettou S, Jung YL, Lenz MO, Taglienti ME, Park PJ, Schermer B, Benzing T, Kreidberg JA. 2015. Genome-wide analysis of Wilms' tumor 1-controlled gene expression in podocytes reveals key regulatory mechanisms. I Am Soc Nephrol 26: 2097-2104. doi:10.1681/ASN.2014090940

Karner CM, Das A, Ma Z, Self M, Chen C, Lum L, Oliver G, Carroll TJ. 2011. Canonical Wnt9b signaling balances progenitor cell expansion and differentiation during kidney development. Development 138: 1247-1257. doi:10.1242/dev.057646

Keller G, Kennedy M, Papayannopoulou T, Wiles MV. 1993. Hematopoietic commitment during embryonic stem cell differentiation in culture. Mol Cell Biol 13: 473-486. doi:10.1128/ MCB.13.1.473

Kim YK, Refaeli I, Brooks CR, Jing P, Gulieva RE, Hughes MR, Cruz NM, Liu Y, Churchill AJ, Wang Y, et al. 2017. Gene-edited human kidney organoids reveal mechanisms of disease in podocyte development. Stem Cells 35: 2366-2378. doi:10 $.1002 /$ stem. 2707

Kobayashi A, Kwan KM, Carroll TJ, McMahon AP, Mendelsohn CL, Behringer RR. 2005. Distinct and sequential tissue-specific activities of the LIM-class homeobox gene Lim 1 for tubular morphogenesis during kidney development. Development 132: 2809-2823. doi:10.1242/dev.01858

Kobayashi A, Valerius MT, Mugford JW, Carroll TJ, Self M, Oliver G, McMahon AP. 2008. Six2 defines and regulates a multipotent self-renewing nephron progenitor population throughout mammalian kidney development. Cell Stem Cell 3: 169-181. doi:10.1016/j.stem.2008.05.020

Kobayashi A, Mugford JW, Krautzberger AM, Naiman N, Liao J, McMahon AP. 2014. Identification of a multipotent self-renewing stromal progenitor population during mammalian 
kidney organogenesis. Stem Cell Reports 3: 650-662. doi:10 .1016/j.stemcr.2014.08.008

Kumar SV, Er PX, Lawlor KT, Motazedian A, Scurr M, Ghobrial I, Combes AN, Zappia L, Oshlack A, Stanley EG, et al. 2019. Kidney micro-organoids in suspension culture as a scalable source of human pluripotent stem cell-derived kidney cells. Development 146: dev172361.

Kuure S, Popsueva A, Jakobson M, Sainio K, Sariola H. 2007. Glycogen synthase kinase-3 inactivation and stabilization of $\beta$ catenin induce nephron differentiation in isolated mouse and rat kidney mesenchymes. J Am Soc Nephrol 18: 11301139. doi:10.1681/ASN.2006111206

Lancaster MA, Knoblich JA. 2014. Organogenesis in a dish: modeling development and disease using organoid technologies. Science 345: 1247125. doi:10.1126/science.1247125

Lancaster MA, Renner M, Martin CA, Wenzel D, Bicknell LS, Hurles ME, Homfray T, Penninger JM, Jackson AP, Knoblich JA. 2013. Cerebral organoids model human brain development and microcephaly. Nature 501: 373-379. doi:10.1038/ nature 12517

Lawlor KT, Zappia L, Lefevre J, Park JS, Hamilton NA, Oshlack A, Little MH, Combes AN. 2019. Nephron progenitor commitment is a stochastic process influenced by cell migration. Elife 8: e41156. doi:10.7554/eLife.41156

Lee JW, Chou CL, Knepper MA. 2015. Deep sequencing in microdissected renal tubules identifies nephron segment-specific transcriptomes. I Am Soc Nephrol 26: 2669-2677. doi:10 $.1681 /$ ASN.2014111067

Lefebvre J, Clarkson M, Massa F, Bradford ST, Charlet A, Buske F, Lacas-Gervais S, Schulz H, Gimpel C, Hata Y, Schaefer F, Schedl A. 2015. Alternatively spliced isoforms of WT1 control podocyte-specific gene expression. Kidney Int 88: 321-331. doi:10.1038/ki.2015.140

Lefevre JG, Chiu HS, Combes AN, Vanslambrouck JM, Ju A, Hamilton NA, Little MH. 2017. Self-organisation after embryonic kidney dissociation is driven via selective adhesion of ureteric epithelial cells. Development 144: 1087-1096. doi:10.1242/dev.140228

Leuning DG, Witjas FMR, Maanaoui M, de Graaf AMA, Lievers E, Geuens T, Avramut CM, Wiersma LE, van den Berg CW, Sol WMPJ, et al. 2019. Vascular bioengineering of scaffolds derived from human discarded transplant kidneys using human pluripotent stem cell-derived endothelium. Am I Transplant 19: 1328-1343. doi:10.1111/ajt.15200

Li Z, Araoka T, Wu J, Liao HK, Li M, Lazo M, Zhou B, Sui Y, Wu MZ, Tamura I, et al. 2016. 3D culture supports long-term expansion of mouse and human nephrogenic progenitors. Cell Stem Cell 19: 516-529. doi:10.1016/j.stem.2016.07.016

Lindstrom NO, Lawrence ML, Burn SF, Johansson JA, Bakker ER, Ridgway RA, Chang CH, Karolak MJ, Oxburgh L, Headon DJ, et al. 2015. Integrated $\beta$-catenin, BMP, PTEN, and Notch signalling patterns the nephron. Elife 4: e04000. doi:10.7554/ eLife.04000

Lindstrom NO, De Sena Brandine G, Tran T, Ransick A, Suh G, Guo J, Kim AD, Parvez RK, Ruffins SW, Rutledge EA, et al. 2018a. Progressive recruitment of mesenchymal progenitors reveals a time-dependent process of cell fate acquisition in mouse and human nephrogenesis. Dev Cell 45: 651-660.e4. doi:10.1016/j.devcel.2018.05.010

Lindstrom NO, Guo J, Kim AD, Tran T, Guo Q, De Sena Brandine G, Ransick A, Parvez RK, Thornton ME, Basking L, et al. 2018b. Conserved and divergent features of mesenchymal progenitor cell types within the cortical nephrogenic niche of the human and mouse kidney. I Am Soc Nephrol 29: 806-824.
Lindstrom NO, McMahon JA, Guo J, Tran T, Guo Q, Rutledge E, Parvez RK, Saribekyan G, Schuler RE, Liao C, et al. 2018c. Conserved and divergent features of human and mouse kidney organogenesis. J Am Soc Nephrol 29: 785-805.

Lindstrom NO, Tran T, Guo J, Rutledge E, Parvez RK, Thornton ME, Grubbs B, McMahon JA, McMahon AP. 2018d. Conserved and divergent molecular and anatomic features of human and mouse nephron patterning. I Am Soc Nephrol 29: 825-840.

Little MH. 2015. Improving our resolution of kidney morphogenesis across time and space. Curr Opin Genet Dev 32: 135-143. doi:10.1016/j.gde.2015.03.001

Little MH, Brennan J, Georgas K, Davies JA, Davidson DR, Baldock RA, Beverdam A, Bertram JF, Capel B, Chiu HS, et al. 2007. A high-resolution anatomical ontology of the developing murine genitourinary tract. Gene Expr Patterns 7: 680699. doi:10.1016/j.modgep.2007.03.002

Little MH, Combes AN, Takasato M. 2016. Understanding kidney morphogenesis to guide renal tissue regeneration. Nat Rev Nephrol 12: 624-635. doi:10.1038/nrneph.2016.126

Lusis M, Li J, Ineson J, Christensen ME, Rice A, Little MH. 2010. Isolation of clonogenic, long-term self renewing embryonic renal stem cells. Stem Cell Res 5: 23-39. doi:10.1016/j.scr.2010 .03 .003

Mae SI, Ryosaka M, Toyoda T, Matsuse K, Oshima Y, Tsujimoto H, Okumura S, Shibasaki A, Osafune K. 2018. Generation of branching ureteric bud tissues from human pluripotent stem cells. Biochem Biophys Res Commun 495: 954-961. doi:10 .1016/j.bbrc.2017.11.105

Magella B, Adam M, Potter AS, Venkatasubramanian M, Chetal K, Hay SB, Salomonis N, Potter SS. 2018. Cross-platform single cell analysis of kidney development shows stromal cells express Gdnf. Dev Biol 434: 36-47. doi:10.1016/j.ydbio.2017 .11 .006

McCright B, Gao X, Shen L, Lozier J, Lan Y, Maguire M, Herzlinger D, Weinmaster G, Jiang R, Gridley T. 2001. Defects in development of the kidney, heart and eye vasculature in mice homozygous for a hypomorphic Notch2 mutation. Development 128: 491-502.

McCracken KW, Cata EM, Crawford CM, Sinagoga KL, Schumacher M, Rockich BE, Tsai YH, Mayhew CN, Spence JR, Zavros Y, et al. 2014. Modelling human development and disease in pluripotent stem-cell-derived gastric organoids. $\mathrm{Na}$ ture 516: 400-404. doi:10.1038/nature 13863

McCracken KW, Aihara E, Martin B, Crawford CM, Broda T, Treguier J, Zhang X, Shannon JM, Montrose MH, Wells JM. 2017. $\mathrm{Wnt} / \beta$-catenin promotes gastric fundus specification in mice and humans. Nature 541: 182-187. doi:10.1038/nature21021

Menon R, Otto EA, Kokoruda A, Zhou J, Zhang Z, Yoon E, Chen YC, Troyanskaya O, Spence JR, Kretzler M, et al. 2018. Singlecell analysis of progenitor cell dynamics and lineage specification in the human fetal kidney. Development 145: dev164038. doi:10.1242/dev.164038

Micallef SJ, Li X, Janes ME, Jackson SA, Sutherland RM, Lew AM, Harrison LC, Elefanty AG, Stanley EG. 2007. Endocrine cells develop within pancreatic bud-like structures derived from mouse ES cells differentiated in response to BMP4 and retinoic acid. Stem Cell Res 1: 25-36. doi:10.1016/j.scr.2007.06.002

Miller AJ, Hill DR, Nagy MS, Aoki Y, Dye BR, Chin AM, Huang S, Zhu F, White ES, Lama V, et al. 2018. In vitro induction and in vivo engraftment of lung bud tip progenitor cells derived from human pluripotent stem cells. Stem Cell Reports 10: 101-119. doi:10.1016/j.stemcr.2017.11.012

Morizane R, Lam AQ, Freedman BS, Kishi S, Valerius MT, Bonventre JV. 2015. Nephron organoids derived from human 
pluripotent stem cells model kidney development and injury. Nat Biotechnol 33: 1193-1200. doi:10.1038/nbt.3392

Mugford JW, Sipilä P, Kobayashi A, Behringer RR, McMahon AP. 2008a. Hoxd11 specifies a program of metanephric kidney development within the intermediate mesoderm of the mouse embryo. Dev Biol 319: 396-405. doi:10.1016/j.ydbio.2008.03 .044

Mugford JW, Sipilä P, McMahon JA, McMahon AP. 2008b. Osr1 expression demarcates a multi-potent population of intermediate mesoderm that undergoes progressive restriction to an Osr1-dependent nephron progenitor compartment within the mammalian kidney. Dev Biol 324: 88-98. doi:10.1016/j .ydbio.2008.09.010

Múnera JO, Sundaram N, Rankin SA, Hill D, Watson C, Mahe M, Vallance JE, Shroyer NF, Sinagoga KL, Zarzoso-Lacoste A, et al. 2017. Differentiation of human pluripotent stem cells into colonic organoids via transient activation of BMP signaling. Cell Stem Cell 21: 51-64.e6. doi:10.1016/j.stem.2017.05 .020

Munro DAD, Hohenstein P, Davies JA. 2017. Cycles of vascular plexus formation within the nephrogenic zone of the developing mouse kidney. Sci Rep 7: 3273. doi:10.1038/s41598-01703808-4

Munro DAD, Wineberg Y, Tarnick J, Vink CS, Li Z, Pridans C, Dzierzak E, Kalisky T, Hohenstein P, Davies JA. 2019. Macrophages restrict the nephrogenic field and promote endothelial connections during kidney development. Elife 8: e43271.

Musah S, Mammoto A, Ferrante TC, Jeanty SSF, Hirano-Kobayashi M, Mammoto T, Roberts K, Chung S, Novak R, Ingram M, et al. 2017. Mature induced-pluripotent-stem-cell-derived human podocytes reconstitute kidney glomerular-capillary-wall function on a chip. Nat Biomed Eng 1: pii:0069. doi:10.1038/ s41551-017-0069

Nakai S, Sugitani Y, Sato H, Ito S, Miura Y, Ogawa M, Nishi M, Jishage K, Minowa O, Noda T. 2003. Crucial roles of Brn1 in distal tubule formation and function in mouse kidney. Development 130: 4751-4759. doi:10.1242/dev.00666

Ng ES, Davis RP, Azzola L, Stanley EG, Elefanty AG. 2005. Forced aggregation of defined numbers of human embryonic stem cells into embryoid bodies fosters robust, reproducible hematopoietic differentiation. Blood 106: 1601-1603. doi:10.1182/ blood-2005-03-0987

Ng ES, Azzola L, Bruveris FF, Calvanese V, Phipson B, Vlahos K, Hirst C, Jokubaitis VJ, Yu QC, Maksimovic J. 2016. Differentiation of human embryonic stem cells to $H O X A^{+}$hemogenic vasculature that resembles the aorta-gonad-mesonephros. Nat Biotechnol 34: 1168-1179.

O'Brien LL, McMahon AP. 2014. Induction and patterning of the metanephric nephron. Semin Cell Dev Biol 36: 31-38. doi:10 $.1016 /$ j.semcdb.2014.08.014

O'Brien LL, Guo Q, Lee Y, Tran T, Benazet JD, Whitney PH, Valouev A, McMahon AP. 2016. Differential regulation of mouse and human nephron progenitors by the Six family of transcriptional regulators. Development 143: 595-608. doi:10.1242/dev.127175

O'Brien LL, Combes AN, Short KM, Lindstrom NO, Whitney PH, Cullen-McEwen LA, Ju A, Abdelhalim A, Michos O, Bertram JF, et al. 2018. Wnt11 directs nephron progenitor polarity and motile behavior ultimately determining nephron endowment. Elife 7: e40392. doi:10.7554/eLife.40392

Oliver J. 1968. Nephrons and Kidneys: A Quantitative Study of Developmental and Evolutionary Mammalian Renal Architectonics. Harper \& Row, New York, NY.

Orlova VV, van den Hil FE, Petrus-Reurer S, Drabsch Y, Ten Dijke P, Mummery CL. 2014. Generation, expansion and functional analysis of endothelial cells and pericytes derived from human pluripotent stem cells. Nat Protoc 9: 1514-1531. doi:10.1038/ nprot.2014.102

Osathanondh V, Potter EL. 1963. Development of human kidney as shown by microdissection. III. Formation and interrelationship of collecting tubules and nephrons. Arch Pathol 76: 290302.

Ozone C, Suga H, Eiraku M, Kadoshima T, Yonemura S, Takata N, Oiso Y, Tsuji T, Sasai Y. 2016. Functional anterior pituitary generated in self-organizing culture of human embryonic stem cells. Nat Commun 7: 10351. doi:10.1038/ncomms 10351

Park J, Shrestha R, Qiu C, Kondo A, Huang S, Werth M, Li M, Barasch J, Suszták K. 2018. Single-cell transcriptomics of the mouse kidney reveals potential cellular targets of kidney disease. Science 360: 758-763. doi:10.1126/science.aar2131

Phipson B, Er PX, Combes AN, Forbes TA, Howden SE, Zappia L, Yen HJ, Lawlor KT, Hale LJ, Sun J, et al. 2019. Evaluation of variability in human kidney organoids. Nat Methods 16: 7987. doi:10.1038/s41592-018-0253-2

Przepiorski A, Sander V, Tran T, Hollywood JA, Sorrenson B, Shih JH, Wolvetang EJ, McMahon AP, Holm TM, Davidson AJ. 2018. A simple bioreactor-based method to generate kidney organoids from pluripotent stem cells. Stem Cell Reports 11: 470-484. doi:10.1016/j.stemcr.2018.06.018

Rae F, Woods K, Sasmono T, Campanale N, Taylor D, Ovchinnikov DA, Grimmond SM, Hume DA, Ricardo SD, Little MH. 2007. Characterisation and trophic functions of murine embryonic macrophages based upon the use of a Csflr-EGFP transgene reporter. Dev Biol 308: 232-246. doi:10.1016/j .ydbio.2007.05.027

Rumballe BA, Georgas KM, Combes AN, Ju AL, Gilbert T, Little MH. 2011. Nephron formation adopts a novel spatial topology at cessation of nephrogenesis. Dev Biol 360: 110-122. doi:10 .1016/j.ydbio.2011.09.011

Rutledge EA, Benazet JD, McMahon AP. 2017. Cellular heterogeneity in the ureteric progenitor niche and distinct profiles of branching morphogenesis in organ development. Development 144: 3177-3188. doi:10.1242/dev.149112

Ryan G, Steele-Perkins V, Morris JF, Rauscher FJ 3rd, Dressler GR. 1995. Repression of Pax-2 by WT1 during normal kidney development. Development 121: 867-875.

Sariola H, Holm K, Henke-Fahle S. 1988. Early innervation of the metanephric kidney. Development 104: 589-599.

Sasai Y. 2013. Cytosystems dynamics in self-organization of tissue architecture. Nature 493: 318-326. doi:10.1038/nature 11859

Saxen L. 1987. Organogenesis of the Kidney (Developmental and Cell Biology Series). Cambridge University Press, Cambridge, United Kingdom.

Saxen L, Sariola H. 1987. Early organogenesis of the kidney. Pediatr Nephrol 1: 385-392. doi:10.1007/BF00849241

Schlieve CR, Fowler KL, Thornton M, Huang S, Hajjali I, Hou X, Grubbs B, Spence JR, Grikscheit TC. 2017. Neural crest cell implantation restores enteric nervous system function and alters the gastrointestinal transcriptome in human tissue-engineered small intestine. Stem Cell Reports 9: 883-896. doi:10 $.1016 /$ j.stemcr.2017.07.017

Self M, Lagutin OV, Bowling B, Hendrix J, Cai Y, Dressler GR, Oliver G. 2006. Six2 is required for suppression of nephrogenesis and progenitor renewal in the developing kidney. EMBO $J$ 25: 5214-5228. doi:10.1038/sj.emboj.7601381

Sharmin S, Taguchi A, Kaku Y, Yoshimura Y, Ohmori T, Sakuma T, Mukoyama M, Yamamoto T, Kurihara H, Nishinakamura R. 2016. Human induced pluripotent stem cell-derived 
podocytes mature into vascularized glomeruli upon experimental transplantation. I Am Soc Nephrol 27: 1778-1791. doi:10.1681/ASN.2015010096

Short KM, Combes AN, Lefevre J, Ju AL, Georgas KM, Lamberton T, Cairncross O, Rumballe BA, McMahon AP, Hamilton NA, et al. 2014. Global quantification of tissue dynamics in the developing mouse kidney. Dev Cell 29: 188-202. doi:10.1016/j .devcel.2014.02.017

Spence JR, Mayhew CN, Rankin SA, Kuhar MF, Vallance JE, Tolle K, Hoskins EE, Kalinichenko VV, Wells SI, Zorn AM, et al. 2011. Directed differentiation of human pluripotent stem cells into intestinal tissue in vitro. Nature 470: 105-109. doi:10.1038/nature09691

Stark K, Vainio S, Vassileva G, McMahon AP. 1994. Epithelial transformation of metanephric mesenchyme in the developing kidney regulated by Wnt-4. Nature 372: 679-683. doi:10 $.1038 / 372679 \mathrm{a} 0$

Subramanian A, Sidhom E-H, Emani M, Sahakian N, Vernon K, Zhou Y, Kost-Alimova M, Weins A, Slyper M, Waldman J, et al. 2019. Kidney organoid reproducibility across multiple human iPSC lines and diminished off target cells after transplantation revealed by single cell transcriptomics. bioRxiv: 516807.

Suga H, Kadoshima T, Minaguchi M, Ohgushi M, Soen $M$, Nakano T, Takata N, Wataya T, Muguruma K, Miyoshi H, et al. 2011. Self-formation of functional adenohypophysis in three-dimensional culture. Nature 480: 57-62. doi:10.1038/ nature 10637

Surendran K, Boyle S, Barak H, Kim M, Stomberski C, McCright B, Kopan R. 2010. The contribution of Notch1 to nephron segmentation in the developing kidney is revealed in a sensitized Notch2 background and can be augmented by reducing Mint dosage. Dev Biol 337: 386-395. doi:10.1016/j.ydbio.2009.11 .017

Taguchi A, Nishinakamura R. 2015. Nephron reconstitution from pluripotent stem cells. Kidney Int 87: 894-900. doi:10 $.1038 /$ ki.2014.358

Taguchi A, Nishinakamura R. 2017. Higher-order kidney organogenesis from pluripotent stem cells. Cell Stem Cell 21: 730746.e6. doi:10.1016/j.stem.2017.10.011

Taguchi A, Kaku Y, Ohmori T, Sharmin S, Ogawa M, Sasaki H, Nishinakamura R. 2014. Redefining the in vivo origin of metanephric nephron progenitors enables generation of complex kidney structures from pluripotent stem cells. Cell Stem Cell 14: 53-67. doi:10.1016/j.stem.2013.11.010

Takahashi K, Yamanaka S. 2006. Induction of pluripotent stem cells from mouse embryonic and adult fibroblast cultures by defined factors. Cell 126: 663-676. doi:10.1016/j.cell.2006.07 .024

Takahashi K, Tanabe K, Ohnuki M, Narita M, Ichisaka T, Tomoda K, Yamanaka S. 2007. Induction of pluripotent stem cells from adult human fibroblasts by defined factors. Cell 131: 861-872. doi:10.1016/j.cell.2007.11.019

Takasato M, Little MH. 2015. The origin of the mammalian kidney: implications for recreating the kidney in vitro. Development 142: 1937-1947. doi:10.1242/dev.104802

Takasato M, Er PX, Becroft M, Vanslambrouck JM, Stanley EG, Elefanty AG, Little MH. 2014. Directing human embryonic stem cell differentiation towards a renal lineage generates a self-organizing kidney. Nat Cell Biol 16: 118-126. doi:10 $.1038 / \mathrm{ncb} 2894$

Takasato M, Er PX, Chiu HS, Maier B, Baillie GJ, Ferguson C, Parton RG, Wolvetang EJ, Roost MS, Chuva de Sousa Lopes SM, et al. 2015. Kidney organoids from human iPS cells contain multiple lineages and model human nephrogenesis. Nature 526: 564-568. doi:10.1038/nature 15695

Takasato M, Er PX, Chiu HS, Little MH. 2016. Generation of kidney organoids from human pluripotent stem cells. Nat Protoc 11: 1681-1692. doi:10.1038/nprot.2016.098

Tanigawa S, Taguchi A, Sharma N, Perantoni AO, Nishinakamura R. 2016. Selective in vitro propagation of nephron progenitors derived from embryos and pluripotent stem cells. Cell Rep 15: 801-813. doi:10.1016/j.celrep.2016.03.076

Tanigawa S, Islam M, Sharmin S, Naganuma H, Yoshimura Y, Haque F, Era T, Nakazato H, Nakanishi K, Sakuma T, et al. 2018. Organoids from nephrotic disease-derived iPSCs identify impaired NEPHRIN localization and slit diaphragm formation in kidney podocytes. Stem Cell Reports 11: 727-740. doi:10.1016/j.stemcr.2018.08.003

Thiagarajan RD, Georgas KM, Rumballe BA, Lesieur E, Chiu HS, Taylor D, Tang DT, Grimmond SM, Little MH. 2011. Identification of anchor genes during kidney development defines ontological relationships, molecular subcompartments and regulatory pathways. PLoS One 6: e17286. doi:10.1371/jour nal.pone.0017286

Thomson JA, Itskovitz-Eldor J, Shapiro SS, Waknitz MA, Swiergiel JJ, Marshall VS, Jones JM. 1998. Embryonic stem cell lines derived from human blastocysts. Science 282: 1145-1147. doi:10.1126/science.282.5391.1145

Trapnell C, Cacchiarelli D, Grimsby J, Pokharel P, Li S, Morse M, Lennon NI, Livak KJ, Mikkelsen TS, Rinn JL. 2014. The dynamics and regulators of cell fate decisions are revealed by pseudotemporal ordering of single cells. Nat Biotechnol 32: 381-386. doi:10.1038/nbt.2859

Treuting P, Kowalewska J. 2011. Urinary System. In Comparative anatomy and histology: a mouse and human atlas (ed. Treuting PM, Dintzis S), pp. 229-251. Academic Press, NY.

Trisno SL, Philo KED, McCracken KW, Cata EM, Ruiz-Torres S, Rankin SA, Han L, Nasr T, Chaturvedi P, Rothenberg ME, et al. 2018. Esophageal organoids from human pluripotent stem cells delineate Sox 2 functions during esophageal specification. Cell Stem Cell 23: 501-515.e7. doi:10.1016/j.stem .2018.08.008

Unbekandt M, Davies JA. 2010. Dissociation of embryonic kidneys followed by reaggregation allows the formation of renal tissues. Kidney Int 77: 407-416. doi:10.1038/ki.2009.482

van den Berg CW, Ritsma L, Avramut MC, Wiersma LE, van den Berg BM, Leuning DG, Lievers E, Koning M, Vanslambrouck JM, Koster AJ, et al. 2018. Renal subcapsular transplantation of PSC-derived kidney organoids induces neo-vasculogenesis and significant glomerular and tubular maturation in vivo. Stem Cell Reports 10: 751-765. doi:10.1016/j.stemcr.2018 .01 .041

Vanslambrouck JM, Wilson SB, Tan KS, Soo JY, Scurr M, Spijker HS, Starks LT, Neilson A, Cui X, Jain S, Little MH, Howden SE. 2019. A toolbox to characterize human induced pluripotent stem cell-derived kidney cell types and organoids. I Am Soc Nephrol pii: ASN.2019030303. doi:10.1681/ASN.2019030303

Vivante A, Hildebrandt F. 2016. Exploring the genetic basis of early-onset chronic kidney disease. Nat Rev Nephrol 12: 133146. doi:10.1038/nrneph.2015.205

Vivante A, Kohl S, Hwang DY, Dworschak GC, Hildebrandt F. 2014. Single-gene causes of congenital anomalies of the kidney and urinary tract (CAKUT) in humans. Pediatr Nephrol 29: 695-704. doi:10.1007/s00467-013-2684-4

Wainwright EN, Wilhelm D, Combes AN, Little MH, Koopman P. 2015. ROBO2 restricts the nephrogenic field and regulates Wolffian duct-nephrogenic cord separation. Dev Biol 404: 88-102. doi:10.1016/j.ydbio.2015.05.023 
Wang P, Chen Y, Yong J, Cui Y, Wang R, Wen L, Qiao J, Tang F. 2018. Dissecting the global dynamic molecular profiles of human fetal kidney development by single-cell RNA sequencing. Cell Rep 24: 3554-3567.e3. doi:10.1016/j.celrep.2018.08 .056

Watanabe T, Costantini F. 2004. Real-time analysis of ureteric bud branching morphogenesis in vitro. Dev Biol 271: 98108. doi:10.1016/j.ydbio.2004.03.025

Wellik DM, Hawkes PJ, Capecchi MR. 2002. Hox11 paralogous genes are essential for metanephric kidney induction. Genes Dev 16: 1423-1432. doi:10.1101/gad.993302

Wu H, Uchimura K, Donnelly EL, Kirita Y, Morris SA, Humphreys BD. 2018. Comparative analysis and refinement of human PSC-derived kidney organoid differentiation with singlecell transcriptomics. Cell Stem Cell 23: 869-881.e8. doi:10 .1016/j.stem.2018.10.010

Xia Y, Nivet E, Sancho-Martinez I, Gallegos T, Suzuki K, Okamura D, Wu MZ, Dubova I, Esteban CR, Montserrat N, et al. 2013. Directed differentiation of human pluripotent cells to ureteric bud kidney progenitor-like cells. Nat Cell Biol 15: 1507-1515. doi:10.1038/ncb2872

$\mathrm{Xu}$ J, Wong EY, Cheng C, Li J, Sharkar MT, Xu CY, Chen B, Sun J, Jing D, Xu PX. 2014. Eya1 interacts with Six2 and Myc to regulate expansion of the nephron progenitor pool during nephro- genesis. Dev Cell 31: 434-447. doi:10.1016/j.devcel.2014.10 .015

Yoshimura Y, Taguchi A, Tanigawa S, Yatsuda J, Kamba T, Takahashi S, Kurihara H, Mukoyama M, Nishinakamura R. 2019. Manipulation of nephron-patterning signals enables selective induction of podocytes from human pluripotent stem cells. I Am Soc Nephrol 30: 304-321. doi:10.1681/ASN.2018070747

Young MD, Mitchell TJ, Vieira Braga FA, Tran MGB, Stewart BJ, Ferdinand JR, Collord G, Botting RA, Popescu DM, Loudon KW, et al. 2018. Single-cell transcriptomes from human kidneys reveal the cellular identity of renal tumors. Science 361: 594-599. doi:10.1126/science.aat 1699

Yu J, Carroll TJ, McMahon AP. 2002. Sonic hedgehog regulates proliferation and differentiation of mesenchymal cells in the mouse metanephric kidney. Development 129: 5301-5312.

Yu J, Carroll TJ, Rajagopal J, Kobayashi A, Ren Q, McMahon AP. 2009. A Wnt7b-dependent pathway regulates the orientation of epithelial cell division and establishes the cortico-medullary axis of the mammalian kidney. Development 136: 161171. doi:10.1242/dev.022087

Zhai XY, Thomsen JS, Birn H, Kristoffersen IB, Andreasen A, Christensen EI. 2006. Three-dimensional reconstruction of the mouse nephron. I Am Soc Nephrol 17: 77-88. doi:10 $.1681 /$ ASN.2005080796 


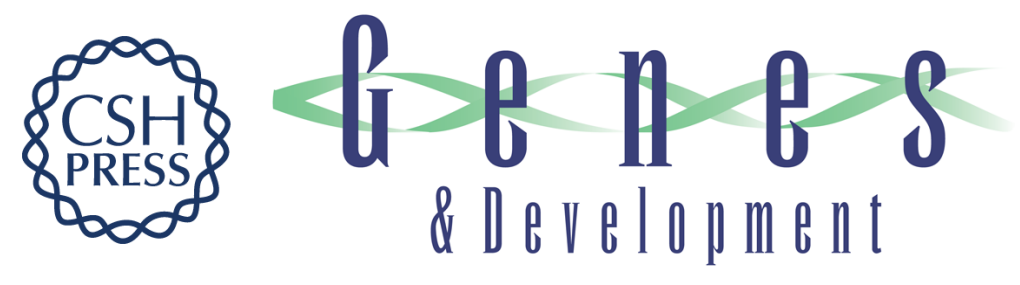

\section{Kidney organoids: accurate models or fortunate accidents}

Melissa H. Little and Alexander N. Combes

Genes Dev. 2019, 33:

Access the most recent version at doi:10.1101/gad.329573.119

References This article cites 152 articles, 44 of which can be accessed free at: http://genesdev.cshlp.org/content/33/19-20/1319.full.html\#ref-list-1

Creative This article is distributed exclusively by Cold Spring Harbor Laboratory Press for the first Commons six months after the full-issue publication date (see License http://genesdev.cshlp.org/site/misc/terms.xhtml). After six months, it is available under a Creative Commons License (Attribution-NonCommercial 4.0 International), as described at http://creativecommons.org/licenses/by-nc/4.0/.

Email Alerting Receive free email alerts when new articles cite this article - sign up in the box at the top Service right corner of the article or click here.

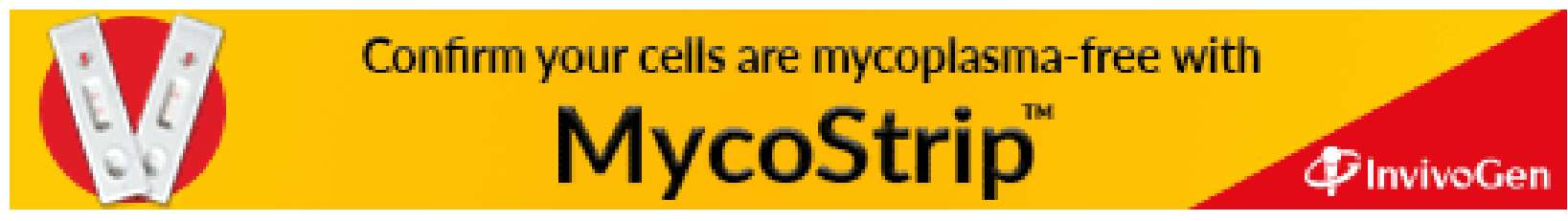

